\title{
Past environmental and climatic changes during the last 7200 cal yr BP in Adamawa plateau (Northern-Cameroun) based on fossil diatoms and sedimentary carbon isotopic records from Lake Mbalang
}

\author{
V. F. Nguetsop ${ }^{1,2}$, I. Bentaleb ${ }^{2}$, C. Favier ${ }^{2}$, C. Martin $^{2}$, S. Bietrix ${ }^{2}$, P. Giresse ${ }^{3}$, S. Servant-Vildary ${ }^{4}$, and M. Servant ${ }^{4}$ \\ ${ }^{1}$ University of Dschang, Department of Plant Biology, P.O. Box 67, Dschang, Cameroon \\ ${ }^{2}$ Equipe Environnement, Université de Montpellier II, ISEM. Place E. Bataillon Bât 22/3e étage/CC 06134095 Montpellier \\ Cedex 05, France \\ ${ }^{3}$ CEFREM, Centre de Formation et de Recherche sur les Environnements Méditerranéens, UMR5110, Université de \\ Perpignan Via Domitia, 52, Avenue Paul Alduy, 66860 Perpignan, France \\ ${ }^{4}$ IRD Bondy, 32, Avenue Henri Varagnat, 93143 Bondy, France
}

Received: 3 December 2010 - Published in Clim. Past Discuss.: 21 January 2011

Revised: 14 October 2011 - Accepted: 20 October 2011 - Published: 12 December 2011

\begin{abstract}
Past limnological conditions of Lake Mbalang $\left(7^{\circ} 19^{\prime} \mathrm{N}, 13^{\circ} 44^{\prime} \mathrm{E}\right.$, altitude: $\left.1130 \mathrm{~m}\right)$ and vegetation type were reconstructed from diatoms and sedimentary stable carbon isotope records $\left(\delta^{13} \mathrm{C}\right)$ since $7200 \mathrm{cal} \mathrm{yr} \mathrm{BP}$. The data showed that before $3600 \mathrm{cal} \mathrm{yr} \mathrm{BP}$, the water column was dominantly stable except around 5000-5300 cal yr BP where diatoms evidenced a mixed upper water layer and $\delta^{13} \mathrm{C}$ data suggest more forested vegetation in the landscape. These stable conditions can be explained by a strong monsoon flux and relatively northern position of the ITCZ that entailed high or low rainfall well distributed over the year, allowing the development of mountainous forest taxa. The decreasing trend of the monsoon flux towards the mid-Holocene was affected by several abrupt centennial to millennial-scale weakening at $6700,5800-6000,5000-5300,4500$ and 3600 cal yr BP. However, their impact on the vegetation is not visible, probably because rainfall distribution was favourable to forest maintenance or extension. After $3600 \mathrm{cal} \mathrm{yr} \mathrm{BP}$, the water column became very mixed as a result of more intense NE trade winds (Harmattan) that led at $\sim 3000 \mathrm{cal}$ yr BP to the establishment of savannah in the vegetation landscape. At that time, rainfall was probably reduced following the southward shift of the ITCZ, and the distribution of yearly rainfall was not favourable anymore to forest development. A strong seasonality with a marked dry season was established, conditions that maintained the savannah vegetation until today.
\end{abstract}

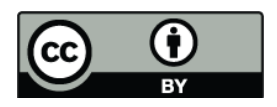

Correspondence to: V. F. Nguetsop (vfnguetsop@yahoo.fr)
Diatom data suggest the lake did not dry up during the last 7200 cal yr BP; however, a low lake level observed at 24002100 cal yr BP is contemporaneous to a climatic event evidenced in several areas of tropical Africa and could correspond to the southernmost position of the ITCZ. Other low lake levels are observed at 1800 and $1400 \mathrm{cal} \mathrm{yr} \mathrm{BP,} \mathrm{after}$ which the lake rose to its present level.

\section{Introduction}

Climatic changes during the Holocene in Western Africa have been mostly studied in the subequatorial forest and Sahelian/arid regions. The two regions are submitted to the atmospheric monsoon flux from the tropical Atlantic that reaches its northern maximum extension during the northern summer (July-August) in the present. It is present over the year in the northern subequatorial regions except during a 3month dry season centered in January. At these latitudes, this monsoon flux is characterised by a deep atmospheric convection; however, a relative stability of the atmosphere at low levels at the base of the monsoon flux is observed in JulyAugust when the Intertropical Convergence Zone (ITCZ) is farthest north. Convective rainfalls are almost suppressed during this period of the year at the northern border of the Guinean Gulf.

During the Holocene, the monsoon flux penetrated more or less deeply inside the Saharan region, entailing an alternation of wet and dry phases (e.g. Servant and ServantVildary, 1980; Gasse, 2000) superimposed on a general trend

Published by Copernicus Publications on behalf of the European Geosciences Union. 
of monsoon weakening in response to decreasing summer insolation of the Northern Hemisphere (Kutzbach and StreetPerrot, 1985). Modifications in the intensity of the monsoon were also suggested by changes of precipitation minus evaporation balance at subequatorial latitudes (Talbot and Delibrias, 1980; Nguetsop et al., 2004).

Concordant data from low and high altitudes in western Cameroon (Maley and Brenac, 1998; Reynaud-Farrera et al., 1996; Nguetsop et al., 1998; Stager and Anfang-Sutter, 1999; Vincens et al., 1999; Ngomanda et al., 2007, 2009b; Kossoni and Giresse, 2009) suggest that climatic changes were also controlled by modifications in the vertical structure of the atmosphere (Nguetsop et al., 2004). The present stable air layer situated at the base of the monsoon flux in JulyAugust could have extended on the western Cameroon lowlands and mid altitude areas during the greatest part of the year, entailing the almost suppression of convective rains before $3000 \mathrm{cal}$ yr BP. After that date, the influence of the stable air layer was strongly reduced and convective rainfall reappeared. If this is true, one can expect different climate evolutions between lowlands south of the Adamawa plateau, mid altitude regions such as Adamawa (1000-1100 m), and western Cameroon highlands ( $>2000 \mathrm{~m}$ ).

Available paleoclimatic records of the last $3000 \mathrm{yr}$ in the tropical zones of Africa, close to the Atlantic coast of Gabon, West-Cameroon and South-Congo (Ngomanda et al., 2009a; Nguetsop et al., 2004; Vincens et al., 1999), suggest significant modifications in abundance and/or seasonal distribution of rainfall in response to north south shift of the Intertropical Convergence zone (ITCZ). Thus, climatic changes affected in the past water resources that impacted on human population and vegetation landscape of central and north tropical Africa. Paleoenvironmental studies showed that the rain forest belt was reduced and persisted only in refuge zones during the Last Glacial maximum (e.g. Maley, 1987). Between $\sim 2500-2000$ cal yr BP, the rain forest was strongly disturbed or was replaced by savannas, depending on the sensibility to climate change of each site in central Atlantic Africa (Vincens et al., 1999). The present day "hot spots" of biodiversity (Tchouto et al., 2006) and the spatial heterogeneity of the rain forest are probably inherited from past climate changes. The question is how the Adamawa plateau located between the dry zones in the north and wet areas in the south responded to theses major climatic changes.

Organic components in lake sediments are supplied by allochtonous organisms and riverine, terrestrial and atmospheric inputs. They are biomarkers of biological production, source organisms, and paleolimnological changes in the drainage basin. Here we study paleolimnological changes inferred from a multi-proxy data set of microfossils and carbon stable isotope ratios of sediment of the core M4 retrieved from Lake Mbalang in the Adamaoua in Cameroon, along with sedimentary facies (Ngos and Giresse, 2011) and AMS carbon-14 datings (Tandetron Accelerator Mass Spectrometry). Specifically, past limnological conditions will be accessed through the analysis of diatom ecological groups; variations in trade wind (Harmattan and monsoon) intensity will be reconstructed from allochtonous diatom taxa or species that characterise stable water table. The evolution of sedimentary $\delta^{13} \mathrm{C}$ will be compared to published palynological data, showing that Lake Mbalang area was only made up of patches of forest surrounded by savannas (with fluctuations of their respective areas) and from ca. $2500 \mathrm{cal}$ yr BP, the region was completely covered by savannas (Vincens et al., 2010). These phenomena are discussed in relation to the Monsoon African System and environmental changes for the last $7000 \mathrm{yr}$.

\section{The site}

\subsection{Location and general characteristics of the studied lake}

Lake Mbalang $\left(7^{\circ} 19^{\prime} \mathrm{N}, 13^{\circ} 44^{\prime} \mathrm{E}\right.$, altitude: $\left.1130 \mathrm{~m}\right)$ lies on the Adamawa plateau that belongs to the Cameroonian volcanic line (Fig. 1). This high topographic unit $(850-1200 \mathrm{~m})$ extends between latitudes $6^{\circ}$ and $8^{\circ}$ north and between longitudes $11^{\circ} 30^{\prime}$ to $15^{\circ} 45^{\prime} \mathrm{E}$. The plateau is limited in the north by the relatively lowlands of the Benue plain (800$300 \mathrm{~m}$ ) and in the south by the sub-Cameroonian plateau $(800-500 \mathrm{~m})$. Crystalline and foliated metamorphic rocks make up the substratum of this unit which is largely covered today by ancient volcanic basaltic flows differently altered from one region to another (Humbel, 1967). According to Gèze (1943), in the Adamawa as well as in the whole volcanic line of Cameroon, three volcanic series can be encountered: the lower black series to which Mbalang region belongs dated from upper Cretaceous to upper Eocene (Bachelier, 1957), the medium white series (end of Neogene) and the upper black series (Quaternary). These series are respectively composed of basalts and andesites conserved as yellowish clays, trachyte and phonolithe lavas, and basaltic volcanic deposits. Volcanic and ferralitic materials in form of dome and outcrops are encountered at the vicinity of the lake. Soils are mostly ferralitic, rich in aluminium and iron oxides with frequent neoformation of halloysite and kaolinite. Other clay minerals present include gibbsite and siderite.

The lake, with a surface area of 50 ha and a narrow watershed ( $\sim 90$ ha), is a volcanic maar described as an asymmetric bowl with steep slopes. Lake Mbalang water maximum depth is about $52 \mathrm{~m}$ and is characterized by the absence of a present day river inlet. The euphotic zone is $3.45 \mathrm{~m}$ deep (Kling, 1987). According to Kling (1987), Lake Mbalang is "moderately stable"; however a relatively cool epilimnion is subjected to period of surface warming in times of low wind stress. The water column is then affected by yearly modifications of mixing depth that could be attributed primarily to higher temperatures as well as intensity of storms or maximum wind speed. The lake is fed only by rainfall and runoff 


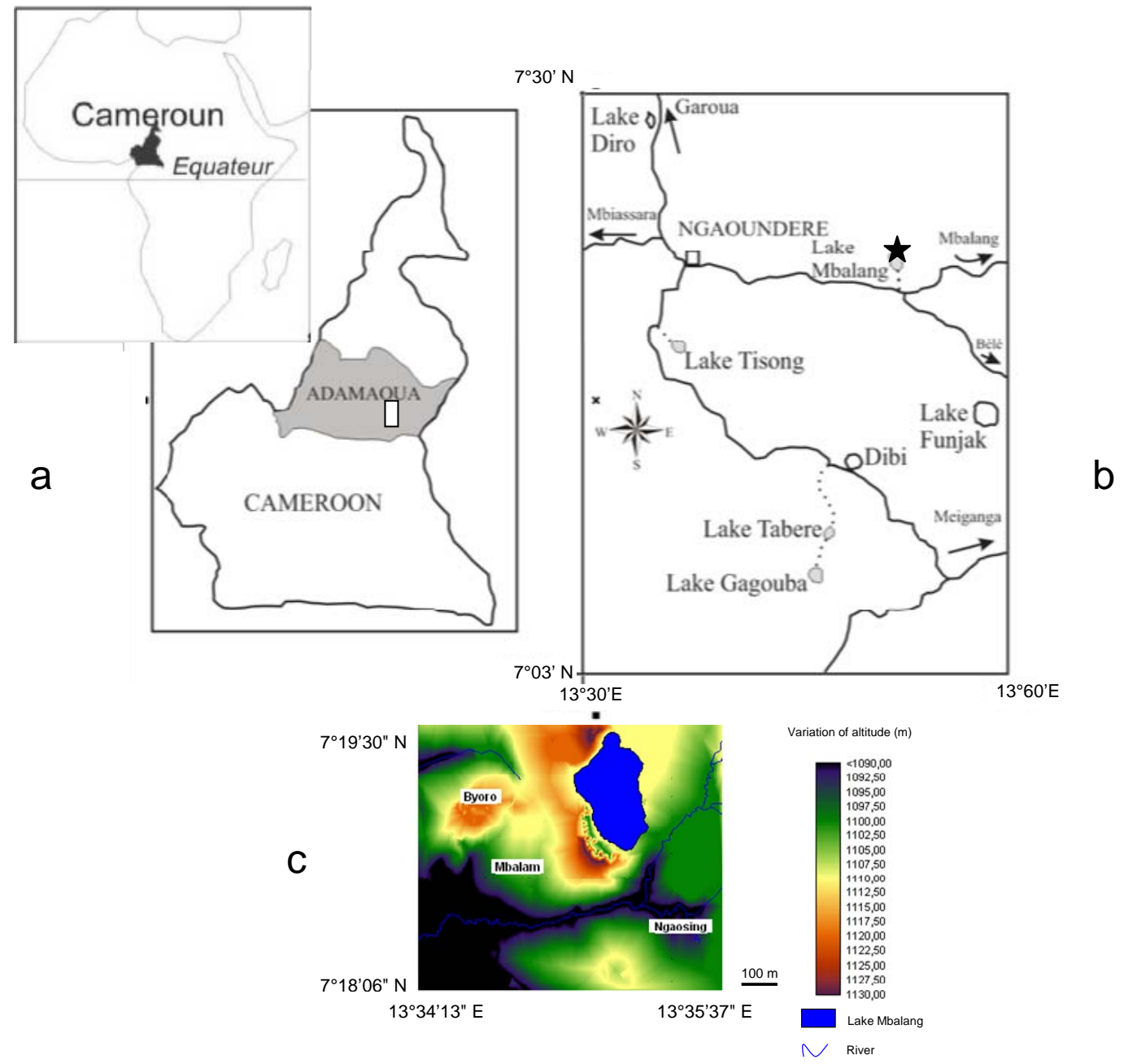

Fig. 1. Location of Lake Mbalang in the Adamawa plateau; morphometric features and area of the lake. The location of the lake is shown with a black star in (b).

from the catchments, water losses occur through evaporation; however a surface outlet is present at the southeastern part of the lake but functions only during very high lake levels over the year. The ${ }^{210} \mathrm{~Pb}$ profiles along the first $80 \mathrm{~cm}$ of the sediment in the lake suggested regular sediment supply from smooth erosion of the surrounding catchments, hence fossil sediments of the lake can be presumably suitable for paleoenvironmental studies (Pourchet et al., 1987).

\subsection{Vegetation}

The Adamawa region is occupied by tree or shrub savannas characterized by Daniellia oliveri (Caesalpiniaceae) and Lophira lanceolata (Ochnaceae); these savannas are strongly altered in some areas due to their permanent use as grazing land. Highest altitudes areas are occupied by soudanoguinean vegetation dominated by Hymenodyction floribundum (Letouzey, 1968, 1985). The edges of the lake are more forested with taxa such as Croton macrostachyus, Sterculia tragacantha, Polyscias fulva, Rauvolfia vomitoria, Pittosporum mannii, Ficus capensis, etc... Typical savanna trees encountered were Annona senegalensis, Allophilus africanus, Cussonia barteri, Piliostigma thonningi, Terminalia glaucescens and Harungana madagascariensis.

\subsection{Climate}

The region is under the influence of the altitudinal tropical climate that shows two distinct seasons: the dry season that last from November to March and the rainy season from April to October with rainfall maxima in July-September. The mean annual rainfall is $1500 \mathrm{~mm}$; mean annual temperature varies from 23 to $26^{\circ} \mathrm{C}$ (Suchel, 1988). In a classic picture, seasonal changes are explained by the displacement during the year of the intertropical convergence zone (ITCZ) in direction of the most heated hemisphere. During the dry 
(a)

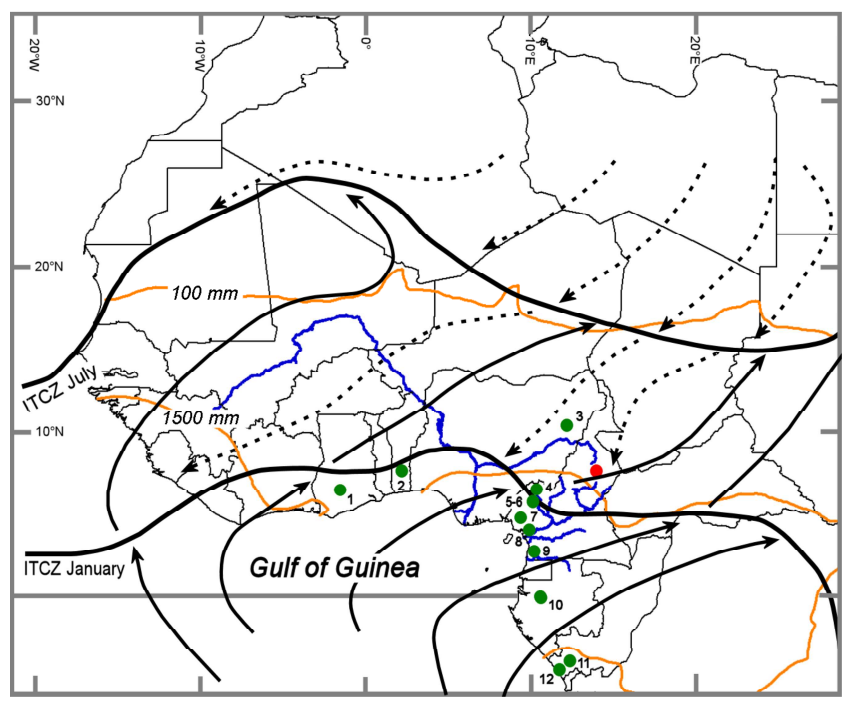

(b)

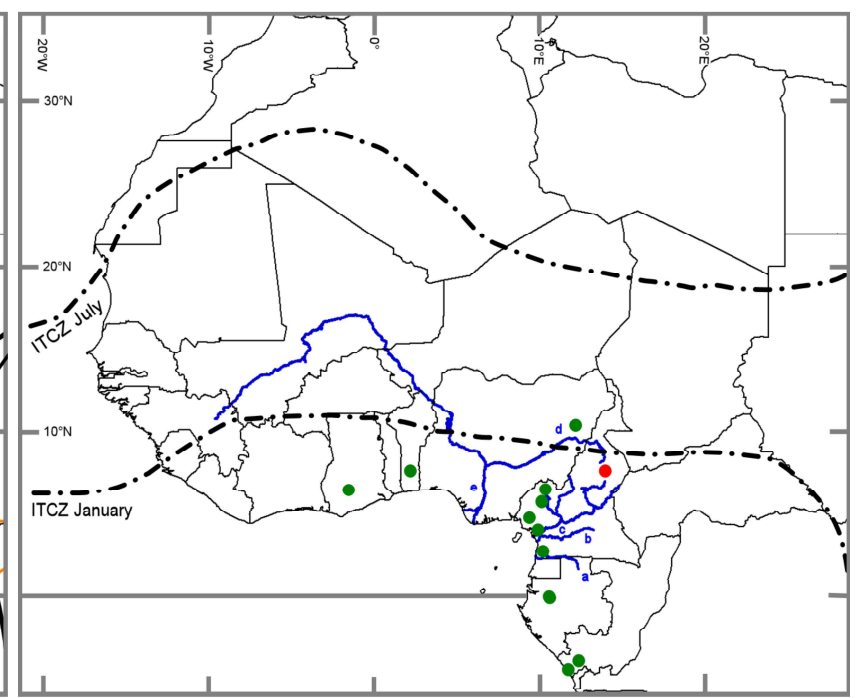

Fig. 2. Map showing the (a) modern positions of Intertropical Convergence Zone (ITCZ) during the northern summer (ITCZ July) and northern winter (ITCZ January). The solid arrows represent the monsoon flux while dotted arrows represent the NE trade winds (Harmattan) (Leroux, 2001). Orange full lines represent isohyetal lines $1500 \mathrm{~mm}$ and $100 \mathrm{~mm}$ (New et al., 2000). Colored dots correspond to sites were paleorecords (green dots) are available: 1 - Bosumtwi, 2 - Sele, 3 - Tilla, 4 - Djupi, 5 - Shum Laka, 6 - Bambili, 7 - Barombi Mbo, 8 - Ossa, 9 - Nyabessan (Ntem River), 10 - Nguène, 11 - Sinnda, 12 - Kitina and Mbalang (red dot). (b) Possible position of ITCZ before 3600 cal yr BP inferred from diatom and $\delta^{13} \mathrm{C}$ isotopic data. Rivers of the Gulf of Guinea: Ntem (a), Nyong (b), Sanaga (c), Benoué (d) and Niger (e).

season (boreal winter), the ITCZ is located south of the Adamawa plateau, the zone is then under the influence of the dry north-eastern trade winds (Harmattan). It moves northwards during the rainy season (boreal summer), the zone is then under the influence of humid south-western air masses (monsoon flux) that bring precipitation (Fig. 2). However, the African easterly waves may strongly modulate the spatial organisation of rainfall over West Africa (Nicholson, 2009).

\section{Material and methods}

\subsection{Description of the core}

The core was collected in March 1998 at the centre part of the lake ( $44 \mathrm{~m}$ deep) with a Mackereth air-compressed corer by Ecofit program team. Lithology and sedimentology of the core M4 has been described by Ngos et al. (2008) and Ngos and Giresse (2011). The lithology of the $6 \mathrm{~m}$ long core showed globally a dark clayey organic mud with clearer/darker laminas at certain levels (Fig. 3a). Coarser sandy laminas (up to $10 \%$ sand in some levels) are observed at the base of the core between 560 and $580 \mathrm{~cm}$ (Ngos et al., 2008; Ngos and Giresse, 2011). Thin-section examinations and XRD analysis of Lake Mbalang core show variable siderite quantities (Ngos et al., 2008). The siderite is ubiquitous but only at small amounts. In few places, nebula-like masses of very small $(<5 \mu \mathrm{m})$ siderites prisms were observed (see Ngos et al., 2008).
Preliminary observations of thin-sections showed that biogenic particles composed of spongiae spicules and diatoms are present throughout the core. Phytoliths and spicules were observed and counted during diatom counting under the light microscope, but not identified to generic or specific levels (Fig. 3b and c). Minerals such as siderite, quartz, feldspars and augite could also be observed in the form of layers or scattered in the sediment (Ngos et al., 2008; Ngos and Giresse, 2011; Fig. 3d).

Spicules were more abundant at the base of the core (587$225 \mathrm{~cm}$ ), the ratio spicules/diatoms (Fig. 3c) counted was relatively high $\left(>20 \times 10^{-2}\right)$. The most important peaks appeared at $535 \mathrm{~cm}\left(3664 \times 10^{-2}\right)$, at $557 \mathrm{~cm}\left(363 \times 10^{-2}\right)$, at $508 \mathrm{~cm}\left(649 \times 10^{2}\right)$ and between 391 and $379 \mathrm{~cm} \mathrm{(403-}$ $\left.500 \times 10^{-2}\right)$. At the upper part of the core, the ratio was generally low $\left(<10 \times 10^{-2}\right)$, the only relatively high values were observed at $182 \mathrm{~cm}\left(89 \times 10^{-2}\right)$ and $67 \mathrm{~cm}\left(35 \times 10^{-2}\right)$. The ratio phytoliths/diatoms followed broadly the same pattern of variation as spicules/diatoms but values are lower (Fig. 3b), peaks were evidenced at $557 \mathrm{~cm}\left(1208 \times 10^{-2}\right), 535 \mathrm{~cm}\left(2545 \times 10^{-2}\right)$ and at $508 \mathrm{~cm}$ $\left(1607 \times 10^{-2}\right)$. Relatively lower ratios were observed between $587-585 \mathrm{~cm}\left(17-31 \times 10^{-2}\right)$, at $544 \mathrm{~cm}\left(141 \times 10^{-2}\right)$ and at $526\left(290 \times 10^{-2}\right)$. A decreasing trend was observed towards the top of the core, the ratio reaches values close to $2 \times 10^{-2}$ between $39-26 \mathrm{~cm}$. 


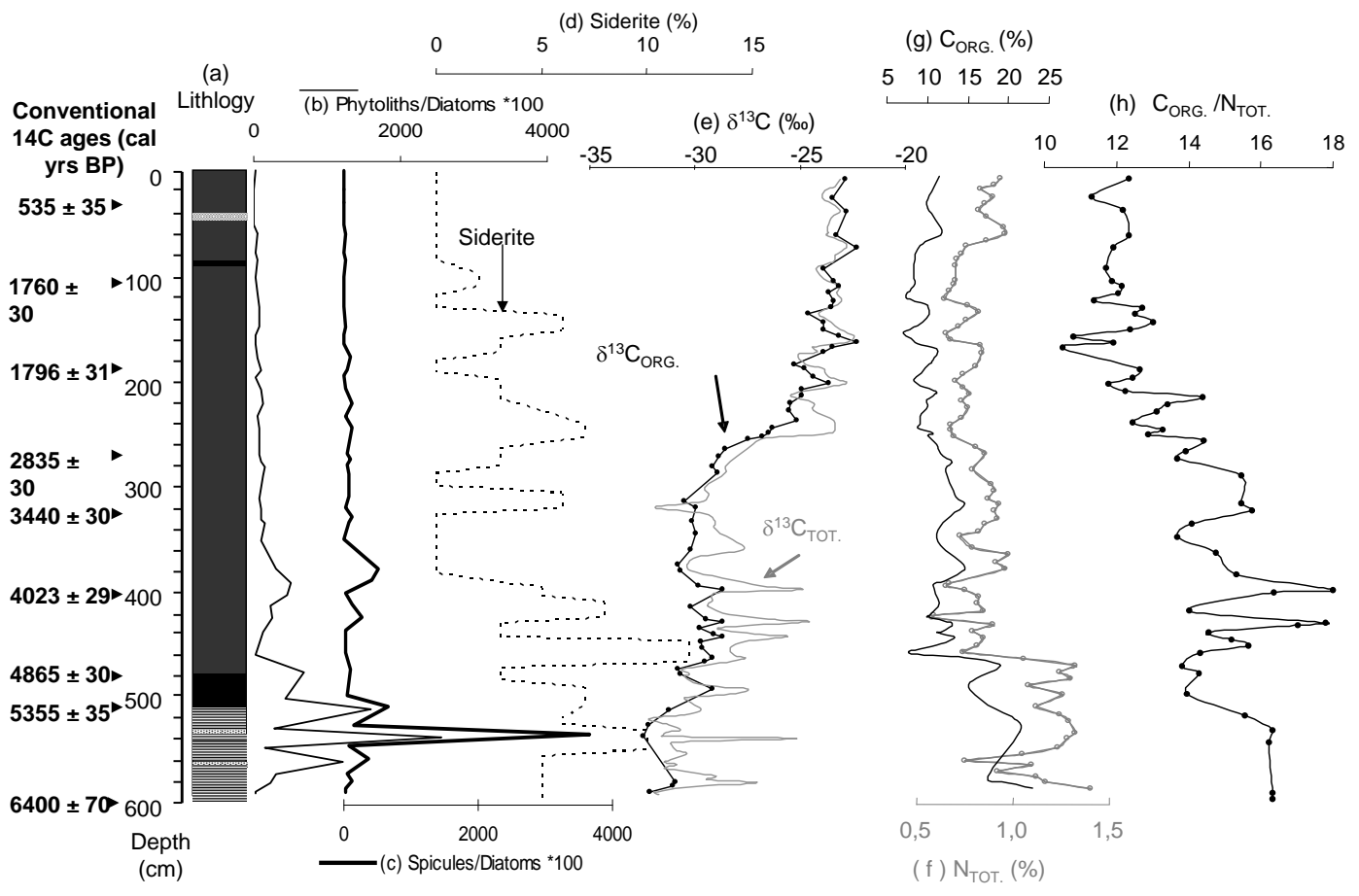

Fig. 3. Lithology of the core M4 modified after Ngos et al. (2008, 2011) radiocarbon ages (a) Phytoliths/Diatoms and Spicules/Diatoms ratios (b and c); siderite occurrence ( \% total crystals), (d); total $\delta^{13} \mathrm{C}\left(\delta^{13} \mathrm{C}_{\mathrm{TOT}}, \%\right.$ o organic $\delta^{13} \mathrm{C}\left(\delta^{13} \mathrm{C}_{\mathrm{ORG}}, \%\right.$ ) (g), total nitrogen $\left(\mathrm{N}_{\mathrm{TOT}}\right.$, $\%, \mathrm{~h})$ total organic carbon $\left(\mathrm{C}_{\mathrm{ORG}}, \%, \mathrm{~g}\right)$ variations and $\mathrm{Corg} / \mathrm{N}_{\mathrm{TOT}}$ (h) changes along the core.

\subsection{Radiocarbon dates}

The chronological control is based on nine AMS radiocarbon dates performed on total organic matter (Table 1). Four of the nine dates (indicated by stars) were already published and discussed in previous articles (Ngos et al., 2008; Vincens et al., 2010). The other five radiocarbon dates were processed at the "Laboratoire de Mesure du Carbone 14 (Salclay, France)" with the ARTEMIS AMS facility. The calibration of ${ }^{14} \mathrm{C}$ yr BP into cal yr BP was performed using the radiocarbon calibration program Calib Rev 6.0 (Stuiver and Reimer, 1993). Eight of the nine dates showed a good internal consistency as function of depth while one performed at $102 \mathrm{~cm}$ appeared older than expected (1760 $\pm 30 \mathrm{yr} \mathrm{BP})$. From Ngos and Giresse (2011) recent study, we know that the volcanic activity of Lake Mbalang was insignificant and that of Lake Tizong located at $15 \mathrm{~km}$ west of Lake Mbalang has been of small radius suggesting $\mathrm{CO}_{2}$ volcanic gases have not affected Lake Mbalang datings. Hence we suggest that older age at $102 \mathrm{~cm}$ cannot be attributed to low radiocarbon activity of volcanic $\mathrm{CO}_{2}$. The older age at $102 \mathrm{~cm}$ may indicates an increase in sedimentation rate as it is observed in Lake Assom (Ngos et al., 2003) and possibly in Lake Tizong in the southern part of Adamawa between 1300 and $2800 \mathrm{yr}$ BP. The lithology of the core did not show any particular unit that could indicate the changes of sedimentation, nevertheless the ratio quartz and plagioclase over kaolonite and gibbsite revealed an elevation of coarse elements in the core at $80-100 \mathrm{~cm}$ (Ngos et al., 2008; Ngos and Giresse, 2011) but the time resolution is not good enough to confirm the change. Here we consider the date older as a result of allochtonous or reworked organic material and consequently the date was excluded in constructing the age model. Assuming that no radiocarbon reservoir age affected the organic carbon of Lake Mbalang the remaining eight dates allowed a construction of a polynomial depth-age model (Fig. 4) in order to calculate by extrapolation the estimated age of each studied sample. This age model was also applied to recent periods (between $535 \mathrm{yr} \mathrm{BP}$ and the present) because ${ }^{210} \mathrm{~Pb}$ analyses are not yet available for accurate calculation of sedimentation rate for that period of time. The polynomial regression intercept near the surface indicates an age of approximately $150 \mathrm{cal}$ yr BP suggesting that reservoir age and volcanic $\mathrm{CO}_{2}$ have little impact on the proposed chronology.

\subsection{Diatom analyses}

Diatom slides were prepared from $\sim 0.5 \mathrm{~g}$ of dry sediment by gently heating in $30 \%$ hydrogen peroxide (Battarbee, 1986) followed by several washings with distilled water. Few drops $(0.2 \mathrm{ml})$ of the resulting residue suspended in distilled water were evaporated onto a coverslip, which was subsequently mounted on a glass slide with Naphrax ${ }^{\mathrm{TM}}$. At least 600 diatom valves were counted per sample or approximately 
Table 1. Radiocarbon dates from the core M4.

\begin{tabular}{|c|c|c|c|c|c|c|}
\hline $\begin{array}{l}\text { Laboratory } \\
\text { codes }\end{array}$ & $\begin{array}{r}\text { Level } \\
(\mathrm{cm})\end{array}$ & Material & $\begin{array}{c}\text { Conventional 14C } \\
\text { ages (cal yr BP) }\end{array}$ & $\begin{array}{r}\text { Calibrated 14C } \\
\text { dates (cal yr BP) }\end{array}$ & $\begin{array}{l}\text { 2-sigma calibrated 14C } \\
\text { ages range (cal yr BP) }\end{array}$ & $\begin{array}{r}\text { Relative area } \\
\text { (probability) }\end{array}$ \\
\hline Unknown & 35 & TOM & $535 \pm 35^{*}$ & 546 & $\begin{array}{l}509-562 \\
594-635\end{array}$ & $\begin{array}{l}0.69859 \\
0.30141\end{array}$ \\
\hline SacA 18586 & 102 & TOM & $1760 \pm 30^{* *}$ & 1664 & $\begin{array}{l}1567-1739 \\
1757-1780 \\
1803-1806\end{array}$ & $\begin{array}{l}0.970552 \\
0.025613 \\
0.003835\end{array}$ \\
\hline Unknown & 185 & TOM & $1796 \pm 31 *$ & 1729 & $\begin{array}{l}1922-1671 \\
1688-1820\end{array}$ & $\begin{array}{l}0.174361 \\
0.825639\end{array}$ \\
\hline SacA 18587 & 276 & TOM & $2835 \pm 30$ & 2939 & $\begin{array}{l}2860-3007 \\
3012-3036 \\
3050-3061\end{array}$ & $\begin{array}{r}0.949524 \\
0.035758 \\
0.0014719\end{array}$ \\
\hline SacA 18588 & 321 & TOM & $3440 \pm 30$ & 3698 & $\begin{array}{l}3631-3780 \\
3787-3828\end{array}$ & $\begin{array}{l}0.826694 \\
0.173306\end{array}$ \\
\hline Unknown & 407 & TOM & $4023 \pm 29 *$ & 4481 & $\begin{array}{l}4421-4536 \\
4542-4549 \\
4555-4568\end{array}$ & $\begin{array}{l}0.949341 \\
0.015457 \\
0.035202\end{array}$ \\
\hline SacA 18589 & 481 & TOM & $4865 \pm 30$ & 5605 & $\begin{array}{l}5490-5501 \\
5583-5654\end{array}$ & $\begin{array}{l}0.02962 \\
0.97038\end{array}$ \\
\hline SacA 18590 & 506 & TOM & $5355 \pm 35$ & 6139 & $\begin{array}{l}6002-6084 \\
6095-6218 \\
6235-6274\end{array}$ & $\begin{array}{r}0.310786 \\
0.555934 \\
0.13328\end{array}$ \\
\hline Beta 143097 & 600 & TOM & $6400 \pm 70^{*}$ & 7333 & $\begin{array}{l}7173-7222 \\
7234-7432\end{array}$ & $\begin{array}{l}0.06448 \\
0.93552\end{array}$ \\
\hline
\end{tabular}

* Dates already published (Ngos et al., 2008; Vincens et al., 2010). ** Date not used in the age model.

200-300 valves when the diatom concentrations were too low. Counts were done at magnification $1000 \times$ with oil immersion objective $(n a=1.32)$ using an Olympus BHT light microscope equipped with Nomarski optics. Diatom preservation was good throughout the core.

Identification and taxonomy of diatoms were based principally on Krammer and Lange-Bertalot (1986-1991), Gasse (1980, 1986), Germain (1981), Schoeman (1973), Simonsen (1987).

Ecological interpretations were essentially based on the modern data of Lake Ossa area (Nguetsop, 1997; Nguetsop et al., 2010) coupled with previously documented taxa preferences in other regions of Africa (Gasse et al., 1995; Servant-Vildary, 1978), for most including taxa counts and water-chemistry characteristics at sampling sites.

\subsection{Stable carbon isotope analyses}

For measurement of carbon stable-isotope content and C/N ratios, 106 samples were taken along the core at intervals varying between 2 and $16 \mathrm{~cm}$ with an average interval sampling of $6 \mathrm{~cm}$. According to Ngos et al. (2008) inorganic carbon (IC) in M4 core is less than 1\% and X-ray diffraction (XRD) siderite (iron carbonate $\mathrm{FeCO}_{3}$ ) estimates show variable relative amount along the core. Bahrig (1988) reported $\delta^{13} \mathrm{C}$ values of siderite ranging from $\sim+2$ to $+15 \%$ o for the siderite $\delta^{13} \mathrm{C}$ though more recent experimental studies of Jimenez-Lopez and Romanek (2004) show that isotopic fractionation of the siderite is close but lower than isotope fractionation factors for the calcite $\mathrm{CO}_{2}(\mathrm{gaz})$. Enriched $\delta^{13} \mathrm{C}$ of carbonates may increase the bulk sedimentary $\delta^{13} \mathrm{C}$ and preclude the interpretation of $\delta^{13} \mathrm{C}$ in terms of organic bulk material. Hence, one should remove siderite by sample pretreatment with acid. However acid treatment methods affect the reliability of organic carbon $(\mathrm{C})$ and nitrogen $(\mathrm{N})$, and 


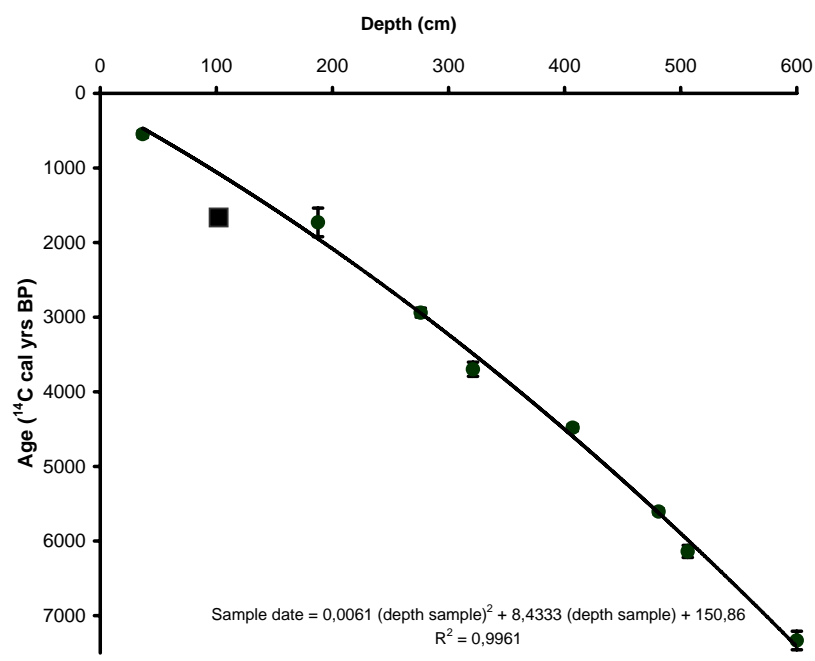

Fig. 4. Calibrated ${ }^{14} \mathrm{C}$ yr BP versus depth in the core M4. The black square represents the measure date that was excluded in the age model.

$\delta^{13} \mathrm{C}$ values (Brodie et al., 2011). Hence, we proceeded to the analysis of $\delta^{13} \mathrm{C}$ of 106 bulk sediment samples of the M4 core without treatment ( $\delta^{13} \mathrm{C}_{\mathrm{TOT}}$.) and 63 among the 106 samples $\left(\delta^{13} \mathrm{C}_{\text {ORG. }}\right)$ were sub-sampled for acid-wash treatment with $\mathrm{HCl}(0.6 \mathrm{~N})$ to remove carbonates (referred as rinse method according to Brodie et al., 2011). Following the recommendations of these authors we included centrifugation steps to minimize the loss of fine colloidal components of the sample material (e.g. fine organic fragments and clays) and reduce potential biasing towards coarser grained fractions. The acid washed samples were rinsed three times with de-ionized water and centrifuged. Bulk sediment and acid-washed samples were dried at $50^{\circ} \mathrm{C}$ for $48 \mathrm{~h}$. About $1 \mathrm{~cm}^{3}$ subsamples were ground using a mortar pilar and sieved through a $60 \mu \mathrm{m}$ mesh. About $0.5 \mathrm{mg}$ bulk sediment powder is weighed and introduced in tin capsules prior to elemental and isotope analysis. Nitrogen content results refer only to the bulk material.

Elemental $\mathrm{C}$ and $\mathrm{N}$ contents (\%) and carbon isotope values of sediment were measured by dry combustion on a Euro Vector 3000 Elemental Analyzer coupled with a Micromass Optima Isotope Ratio Mass Spectrometer at ISEM laboratory (Montpellier). Elemental analysis of total carbon ( $\mathrm{C}_{\mathrm{TOT}}$.), total organic carbon $\left(\mathrm{C}_{\mathrm{ORG}}\right.$.) and total nitrogen ( $\mathrm{N}_{\text {TOT. }}$ ) and therefore $\mathrm{C} / \mathrm{N}$ ratios were measured using the $\mathrm{C}$ and $\mathrm{N}$ contents of the alanine standard $(\mathrm{C} \%=40, \mathrm{~N} \%=16)$. The analytical precision of the $\mathrm{N} \%$ and $\mathrm{C} \%$ is about $1 \%$. The $\delta^{13} \mathrm{C}$ results are expressed in delta $(\delta)$ notation where: $\delta(\% o)=\left[\left(R_{\text {sample }} / R_{\text {standard }}\right)-1\right] \times 1000$ where $R_{\text {sample }}$ and $R_{\text {standard }}$ refer to the ${ }^{13} \mathrm{C} /{ }^{12} \mathrm{C}$ ratios of sample and standard, respectively. $\quad \delta^{13} \mathrm{C}$ values are reported in parts per thousand (\%o) relative to the Vienna Pee Dee Belemnite (VPDB) standard. Precision for isotope measurements of chemical standards (Nist-8541 graphite international standards and alanine) within sample runs were better than $0.2 \%$.

\section{Results and interpretations}

A total of 98 species and varieties of diatoms were identified in the 48 studied samples of the core M4. Figure 5 shows the evolution of the most represented species ( $\geq 5 \%$ in at least one sample). The ecological preferences of diatoms allowed the individualization of 2 major phases (with 6 sub-phases) in the paleohydrological evolution of the lake. Planktonic and tychoplanktonic diatoms were present throughout the core indicating that Lake Mbalang has never dried up (Figs. 6b, c, $\mathrm{d}$ and $7 \mathrm{a}$ ). This assumption is reinforced by the fact that benthic, epiphytic and aerophilic diatoms remained consistently low along the core (Figs. 6e, f, g and 7a). Some diatoms that were recognised to be allochtonous were excluded from the diatom percentage calculations and sum (Fig. 5).

We measured $\delta^{13} \mathrm{C}_{\text {TOT. }}, \mathrm{C}_{\text {TOT. }}$. and $\mathrm{N}_{\text {TOT. }}$. contents and $\mathrm{C}_{\text {TOT. }} / \mathrm{N}_{\text {TOT. ratios of }} 106$ bulk samples and $\delta^{13} \mathrm{C}_{\text {ORG. }}, \mathrm{C}_{\text {ORG. }}$ and $\mathrm{C}_{\mathrm{ORG}} / \mathrm{N}_{\mathrm{TOT}}$. of 63 carbonate free samples of $\mathrm{M} 4$ core (Table 2 and Fig. 3e, g and h). Both curves of $\delta^{13} \mathrm{C}_{\mathrm{TOT}}$ and $\delta^{13} \mathrm{C}_{\mathrm{ORG}}$ show the same trend. However, between 400 and $600 \mathrm{~cm}$, and 220 and $240 \mathrm{~cm}$ the $\delta^{13} \mathrm{C}_{\mathrm{ORG}}$ show more depleted values compare to $\delta^{13} \mathrm{C}_{\mathrm{TOT}}$. The isotopic difference between untreated and treated samples may reach $4 \%$ $(426 \mathrm{~cm})$ likely due to siderite reaching $10-12 \%$ of mineral crystals at those depths (Fig. 3d).

According to Ngos and Giresse (2011) the organic carbon content fluctuates between 15 and $20 \%$ in the lower two thirds portion of the sedimentary column before dropping, to $10 \%$ in the upper part i.e. during the last 2500 cal yr BP. Our new data of $\mathrm{C}_{\text {TOT. }}$ (6.5 to $21.5 \%$ ) and $\mathrm{C}_{\text {ORG. }}$ (7.1 to $22.9 \%$ ) and $\mathrm{N}_{\text {TOT }}(0.6$ to $1.4 \%$ ) confirm this change (Fig. $3 \mathrm{~g}$ ).

Lake sedimentary organic matter may results from a complex combination of sources: autochtonous organisms (freshwater food chain) and/or allochtonous material (terrestrial riverine and atmospheric inputs). Hence the isotopic composition of the lake organic matter may reflect a mixture of these diverse sources. Generally autochtonous lacustrine organic matter is characterised by relatively low $\mathrm{C} / \mathrm{N}$ ratios, typically $<10$ (Meybeck, 1982) and terrestrial plants have high $\mathrm{C} / \mathrm{N}$ ratios (>20 and may be $>200$; Hedges et al., 1986). Talbot et al. (1992) reported $\mathrm{C} / \mathrm{N}$ ratios for plants collected near the Lake Bosumtwi varying between 26.4 and 156.3.

The M4 core $\mathrm{C} / \mathrm{N}$ ratios of untreated and acid washed samples range from 9.7 to 17.9 and 10.5 to 18.0 respectively (Table 2) showing that $\mathrm{C}_{\text {ORG. }} \mathrm{N}_{\text {TOT. }}$ ratios are slightly higher than $\mathrm{C}_{\mathrm{TOT}}$. $/ \mathrm{N}_{\mathrm{TOT}}$. In average, the $\mathrm{C}_{\mathrm{ORG}}$. is $1.3 \pm 06 \%$ higher than $\mathrm{C}_{\text {TOT. }}$. taking into account the precision of $1 \%$, we can assume that the difference is not significant. However, according to Brodie et al. (2011) the acid treatment using the rinse method can artificially elevate $C$ values due to the loss of fine-grained materials (e.g. such as clays) and the removal of inorganic carbon. The highest $\mathrm{C} / \mathrm{N}$ values are observed between 600 and $300 \mathrm{~cm}$ with a mean value of $14.0 \pm 1.2$ (untreated samples) and 15.6 \pm 1.2 (treated samples). Between $300 \mathrm{~cm}$ and the top of M4 core, the mean 


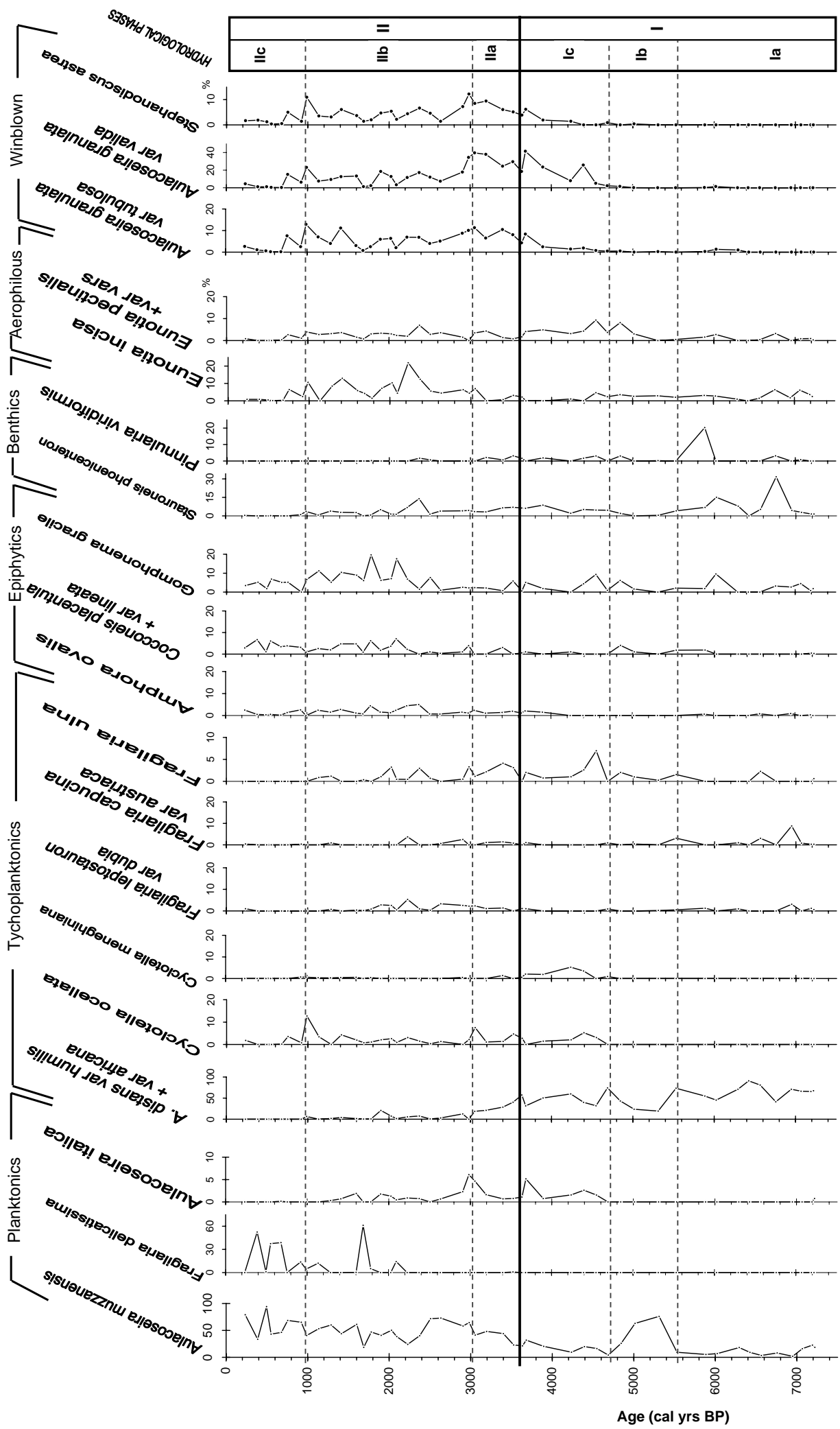

Fig. 5. Variation in abundances of the most dominant taxa ( $>5 \%$ in at least one sample) belonging to different habitat groups and windblown diatoms over the core. Hydrological phases corresponding to diatom zones are indicated. 

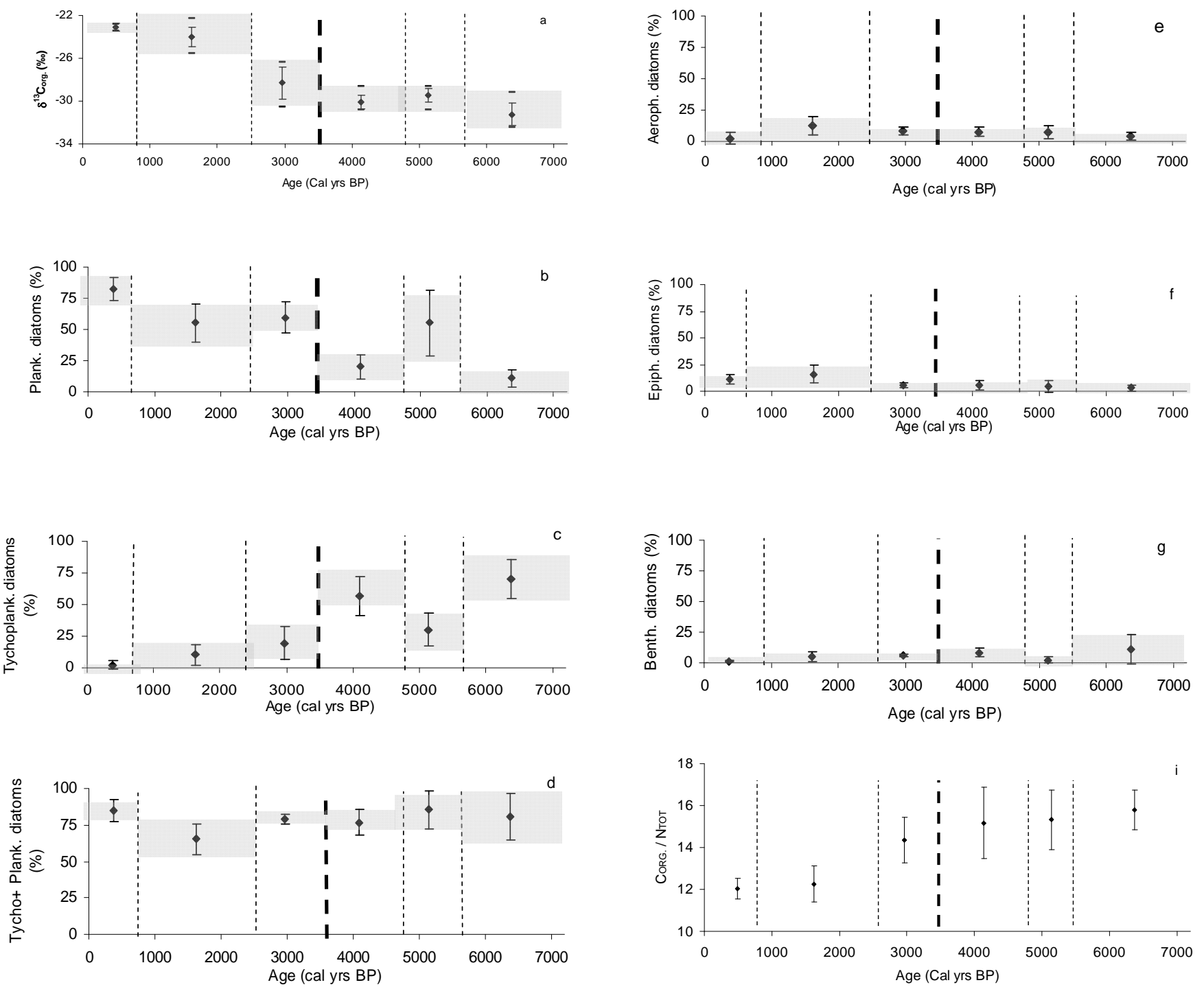

Fig. 6. Mean values and standard deviations of each diatom (b to $\mathbf{g})$ habitat group (\%) and $\delta^{13} \mathrm{C}(\mathbf{a}) . \delta^{13} \mathrm{C}$ extreme values are also reported. The dashed lines highlight the phase thresholds defined by diatom stratigraphy along the core.

$\mathrm{C} / \mathrm{N}$ value decreases $(11.0 \pm 0.8$ and $12.6 \pm 1.1$ for untreated and treated samples respectively). Do these values reflect a change in the proportion of terrestrial versus aquatic organic carbon inputs to Lake Mbalang? One can suggest that values of M4 core (from $\sim 12$ to $\sim 15$ ) may reflect a mixture of aquatic and terrestrial organic carbon and hence that the aquatic contribution tend to increase from the base to the top of M4 core. However, according to unpublished $\mathrm{C} / \mathrm{N}$ data , a different interpretation for relatively low $\mathrm{C} / \mathrm{N}$ ratios can be proposed. Modern soil of Central Africa in savanna area have been analyzed with a multi-proxy mean approach (see Fig. 2, Aleman et al., 2011). Measured $\mathrm{C} / \mathrm{N}$ ratios vary from 10 to 19.3 . These relatively low $\mathrm{C} / \mathrm{N}$ ratios of terrestrial material show intermediate values of $\mathrm{C} / \mathrm{N}$ are not necessarily linked to a mixture of aquatic and terrestrial organic carbon and that more study and data collection are necessary to understand the processes behind the $\mathrm{C} / \mathrm{N}$ variations in plants, soils and lacustrine algae of Africa. Finally, erosional exposition and/or long distance transport of terrestrial organic matter can also increase the $\mathrm{C} / \mathrm{N}$ ratios.

The analyses of $\delta^{13} \mathrm{C}_{\mathrm{ORG}}$. along the core show two main phases and a transitional phase ( 3400 to $2500 \mathrm{cal} \mathrm{yr} \mathrm{BP}$ ): depleted values varying between -32.4 and $-28.7 \%$ are observed between $\sim 7200$ and $\sim 3400$ cal yr BP (mean value of $-30.2 \pm 1.1 \%$ ) and enriched $\delta^{13} \mathrm{C}_{\mathrm{TOC}}$ values $(\sim-26.3$ to $-22.3 \%$ ) concomitant with Poaceae pollen increase (Vincens et al., 2010) for the last $\sim 2500$ cal yr BP (Figs. 6a and 7d).

According to Roberts et al. (2001), high lacustrine primary production (mostly algae) may increase the lacustrine isotopic carbon composition values by up $15 \%$ due to the high $\mathrm{CO}_{2}$ biological demand during photosynthetic 
Table 2. Stable carbon and elemental analysis of $\mathrm{M} 4$ sedimentary core taken in Lake Mbalang.Total $\delta^{13} \mathrm{C}\left(\delta^{13} \mathrm{C}_{\mathrm{TOT}}\right.$. $\%$ o $)$ and total carbon $\left(\% \mathrm{C}_{\mathrm{TOT}}\right.$.) and nitrogen $\left(\% \mathrm{~N}_{\mathrm{TOT}}\right.$.) refer to analysis made on the total sedimentary material (without acid treatment). $\delta^{13} \mathrm{C}_{\mathrm{ORG}}$ and $\mathrm{C}_{\mathrm{ORG}}$. (\%) refer to analysis of the organic carbon fraction (after $\mathrm{HCl}$ treatment). $\mathrm{C} / \mathrm{N}$ ratios are calculated for both total $\left(\mathrm{C}_{\mathrm{TOT}} / \mathrm{N}_{\mathrm{TOT}}\right)$ and organic carbon ( $\mathrm{C}_{\mathrm{ORG}} . \mathrm{N}_{\mathrm{TOT}}$. $)$.

\begin{tabular}{|c|c|c|c|c|c|c|c|c|c|}
\hline $\begin{array}{l}\text { Sample } \\
\text { Number }\end{array}$ & $\begin{array}{r}\text { Depth } \\
(\mathrm{cm})\end{array}$ & $\begin{array}{r}\text { Age } \\
(\mathrm{Cal} \text { Yr BP })\end{array}$ & $\delta^{13} \mathrm{C}_{\mathrm{TOT}}$ & $\begin{array}{r}\mathrm{C}_{\mathrm{TOT}} \\
(\%)\end{array}$ & $\begin{array}{r}\mathrm{N}_{\mathrm{TOT}} \\
(\%)\end{array}$ & $\mathrm{C}_{\mathrm{TOT}} / \mathrm{N}_{\mathrm{TOT}}$ & $\delta^{13} \mathrm{C}_{\mathrm{ORG}}$ & $\begin{array}{r}\mathrm{C}_{\mathrm{ORG}} \\
(\%)\end{array}$ & $\mathrm{C}_{\mathrm{ORG} .} / \mathrm{N}_{\mathrm{TOT}}$ \\
\hline 1 & 10 & 234 & -23.1 & 10.2 & 0.9 & 10.9 & -22.84 & 11.50 & 12.3 \\
\hline 4 & 16 & 289 & -23.4 & 9.4 & 0.9 & 10.4 & & & \\
\hline 6 & 20 & 321 & -23.8 & 8.8 & 0.8 & 10.6 & & & \\
\hline 9 & 27 & 387 & -24.0 & 9.5 & 0.9 & 10.6 & -23.44 & 10.13 & 11.3 \\
\hline 12 & 34 & 440 & -23.3 & 8.9 & 0.9 & 10.4 & & & \\
\hline 15 & 40 & 495 & -23.1 & 8.2 & 0.8 & 10.0 & -22.80 & 9.98 & 12.2 \\
\hline 18 & 46 & 552 & -23.5 & 8.8 & 0.9 & 10.2 & & & \\
\hline 21 & 56 & 644 & -23.7 & 9.6 & 1.0 & 10.1 & & & \\
\hline 23 & 60 & 679 & -23.6 & & & & & & \\
\hline 24 & 62 & 700 & -23.7 & 10.2 & 1.0 & 10.6 & -23.28 & 11.82 & 12.3 \\
\hline 27 & 68 & 755 & -23.0 & 9.5 & 0.9 & 11.0 & & & \\
\hline 30 & 74 & 811 & -22.8 & 7.7 & 0.8 & 10.2 & -22.29 & 9.02 & 11.9 \\
\hline 34 & 81 & 873 & -23.3 & 7.5 & 0.7 & 10.2 & & & \\
\hline 37 & 86 & 921 & -23.4 & 7.4 & 0.7 & 10.5 & & & \\
\hline 40 & 93 & 988 & -24.3 & 7.4 & 0.7 & 10.5 & -23.91 & 8.26 & 11.7 \\
\hline 45 & 106 & 1110 & -23.7 & 7.5 & 0.7 & 10.7 & -23.40 & 8.36 & 11.9 \\
\hline 47 & 110 & 1155 & -23.1 & 7.4 & 0.7 & 10.8 & -23.18 & 8.40 & 12.2 \\
\hline 50 & 116 & 1214 & -23.3 & 6.9 & 0.7 & 10.2 & -23.65 & 8.07 & 12.0 \\
\hline 53 & 124 & 1287 & -23.0 & 6.5 & 0.6 & 10.1 & -23.39 & 7.35 & 11.4 \\
\hline 56 & 130 & 1346 & -23.5 & 8.6 & 0.8 & 11.2 & -23.53 & 9.72 & 12.7 \\
\hline 59 & 136 & 1413 & -24.1 & 9.1 & 0.8 & 11.1 & -24.64 & 10.27 & 12.5 \\
\hline 62 & 144 & 1489 & -23.5 & 8.6 & 0.8 & 11.4 & -23.90 & 9.82 & 13.0 \\
\hline 65 & 150 & 1557 & -23.1 & 7.6 & 0.7 & 10.7 & -23.91 & 8.83 & 12.4 \\
\hline 68 & 157 & 1622 & -22.5 & 6.6 & 0.7 & 10.1 & -23.13 & 7.08 & 10.8 \\
\hline 71 & 163 & 1688 & -22.8 & 6.8 & 0.7 & 10.1 & -22.31 & 8.04 & 11.9 \\
\hline 73 & 167 & 1730 & -24.4 & 8.0 & 0.8 & 9.7 & -23.48 & 8.71 & 10.5 \\
\hline 75 & 172 & 1780 & -24.2 & & & & -23.89 & 11.18 & \\
\hline 76 & 175 & 1811 & -25.1 & 9.5 & 0.8 & 11.3 & & & \\
\hline 78 & 183 & 1901 & -24.7 & & & & -25.27 & 10.61 & \\
\hline 80 & 187 & 1944 & -24.0 & 9.2 & 0.8 & 11.4 & -24.78 & 10.25 & 12.7 \\
\hline 83 & 195 & 2027 & -23.7 & 8.2 & 0.7 & 11.0 & -24.36 & 9.24 & 12.4 \\
\hline 86 & 201 & 2093 & -22.8 & 7.4 & 0.7 & 10.6 & -23.65 & 8.28 & 11.8 \\
\hline 89 & 207 & 2159 & -24.2 & 8.1 & 0.7 & 11.0 & -24.91 & 9.07 & 12.3 \\
\hline 92 & 213 & 2227 & -25.5 & 8.6 & 0.8 & 11.2 & -24.93 & 11.09 & 14.4 \\
\hline 95 & 220 & 2301 & -24.4 & 8.9 & 0.7 & 12.1 & -25.45 & 9.87 & 13.4 \\
\hline 98 & 227 & 2374 & -24.4 & 8.9 & 0.8 & 11.5 & -25.52 & 10.08 & 13.1 \\
\hline 101 & 236 & 2482 & -23.4 & 8.5 & 0.7 & 11.5 & -25.13 & 9.17 & 12.4 \\
\hline 104 & 243 & 2560 & -23.4 & 8.0 & 0.7 & 11.8 & -26.33 & 9.02 & 13.3 \\
\hline 106 & 247 & 2611 & -23.5 & 7.8 & 0.7 & 11.5 & -26.47 & 8.71 & 12.9 \\
\hline 108 & 252 & 2663 & -25.6 & & & & -26.79 & 10.63 & \\
\hline 109 & 254 & 2686 & -26.8 & 8.4 & 0.7 & 12.0 & -27.45 & 10.05 & 14.4 \\
\hline 112 & 263 & 2793 & -27.5 & 9.7 & 0.8 & 12.5 & -28.56 & 11.18 & 13.9 \\
\hline 115 & 271 & 2878 & -28.0 & 10.6 & 0.9 & 12.4 & -28.90 & 11.67 & 13.7 \\
\hline 119 & 279 & 2982 & -28.6 & & & & -29.19 & 13.07 & \\
\hline 120 & 286 & 3056 & -28.6 & 10.1 & 0.8 & 12.7 & -28.94 & 12.20 & 15.5 \\
\hline 123 & 299 & 3219 & -29.5 & 11.7 & 0.9 & 13.2 & & & \\
\hline 126 & 306 & 3297 & -29.4 & 11.8 & 0.9 & 13.0 & & & \\
\hline 129 & 312 & 3375 & -29.6 & 11.7 & 0.9 & 14.0 & -30.51 & 13.47 & 15.5 \\
\hline 132 & 318 & 3451 & -31.9 & 12.8 & 0.9 & 14.3 & -29.96 & 14.64 & 15.8 \\
\hline 135 & 324 & 3527 & -29.5 & 12.3 & 0.9 & 14.2 & & & \\
\hline 138 & 331 & 3607 & -29.1 & 11.5 & 0.9 & 12.5 & -30.15 & 12.93 & 14.1 \\
\hline 141 & 337 & 3681 & -29.1 & 11.2 & 0.9 & 13.0 & & & \\
\hline
\end{tabular}


Table 2. Continued.

\begin{tabular}{|c|c|c|c|c|c|c|c|c|c|}
\hline $\begin{array}{l}\text { Sample } \\
\text { Number }\end{array}$ & $\begin{array}{r}\text { Depth } \\
(\mathrm{cm})\end{array}$ & $\begin{array}{r}\text { Age } \\
(\mathrm{Cal} \text { Yr BP })\end{array}$ & $\delta^{13} \mathrm{C}_{\mathrm{TOT}}$ & $\begin{array}{r}\mathrm{C}_{\mathrm{TOT}} \\
(\%)\end{array}$ & $\begin{array}{r}\mathrm{N}_{\mathrm{TOT}} \\
(\%)\end{array}$ & $\mathrm{C}_{\mathrm{TOT}} \cdot \mathrm{N}_{\mathrm{TOT}}$ & $\delta^{13} \mathrm{C}_{\mathrm{ORG}}$ & $\begin{array}{r}\mathrm{C}_{\mathrm{ORG}} \\
(\%)\end{array}$ & $\mathrm{C}_{\mathrm{ORG} .} / \mathrm{N}_{\mathrm{TOT}}$. \\
\hline 144 & 343 & 3764 & -28.8 & 10.6 & 0.8 & 12.9 & -29.99 & 11.29 & 13.7 \\
\hline 146 & 348 & 3824 & -28.2 & 9.2 & 0.7 & 12.8 & & & \\
\hline 149 & 358 & 3954 & -27.7 & 10.7 & 0.8 & 13.5 & -30.20 & 11.67 & 14.7 \\
\hline 152 & 365 & 4047 & -29.9 & 11.3 & 1.0 & 11.6 & & & \\
\hline 155 & 372 & 4135 & -30.4 & 13.0 & 0.9 & 14.9 & -30.82 & & \\
\hline 158 & 378 & 4215 & -30.2 & 13.5 & 1.0 & 14.9 & -30.69 & 14.66 & 15.3 \\
\hline 162 & 392 & 4394 & -26.9 & 10.2 & 0.7 & 15.9 & -29.82 & 12.03 & 18.0 \\
\hline 163 & 395 & 4432 & -24.9 & 10.2 & 0.7 & 15.3 & -28.67 & 10.65 & 16.4 \\
\hline 165 & 399 & 4490 & -29.1 & 10.6 & 0.8 & 14.8 & & & \\
\hline 168 & 406 & 4574 & -29.2 & 11.1 & 0.8 & 13.5 & & & \\
\hline 171 & 412 & 4654 & -29.3 & 11.0 & 0.8 & 13.5 & -30.19 & 11.44 & 14.0 \\
\hline 174 & 418 & 4745 & -28.4 & 11.6 & 0.8 & 13.7 & & & \\
\hline 176 & 423 & 4810 & -26.5 & 10 & 0.6 & 17.9 & -29.44 & 10.42 & 17.8 \\
\hline 177 & 426 & 4845 & -24.6 & 9.3 & 0.6 & 17.2 & -28.66 & 9.84 & 17.0 \\
\hline 180 & 432 & 4930 & -28.9 & 12.1 & 0.9 & 13.5 & -29.75 & 13.00 & 14.6 \\
\hline 183 & 438 & 5015 & -26.9 & 10.9 & 0.8 & 13.9 & -29.08 & 11.95 & 15.2 \\
\hline 184 & 440 & 5047 & -25.6 & & & & -28.68 & 11.14 & \\
\hline 186 & 444 & 5101 & -27.6 & 11.7 & 0.8 & 13.8 & -29.72 & 13.29 & 15.7 \\
\hline 189 & 451 & 5192 & -28.3 & 10.9 & 0.8 & 13.4 & -29.67 & 11.67 & 14.3 \\
\hline 192 & 457 & 5282 & -28.1 & 10.1 & 0.7 & 13.7 & & & \\
\hline 193 & 459 & 5310 & -27.6 & & & & -29.19 & 7.71 & \\
\hline 195 & 464 & 5372 & -28.2 & 13.07 & 1.1 & 12.3 & -29.56 & 14.66 & 13.8 \\
\hline 198 & 470 & 5466 & -30.6 & 17.11 & 1.3 & 13.0 & -30.81 & 18.86 & 14.3 \\
\hline 200 & 475 & 5530 & -30.3 & 17 & & & -30.66 & 18.46 & \\
\hline 201 & 477 & 5559 & -30.5 & 15.74 & 1.2 & 12.7 & & & \\
\hline 204 & 483 & 5647 & -30.1 & 16.33 & 1.3 & 12.6 & & & \\
\hline 206 & 487 & 5705 & -28.9 & & & & & & \\
\hline 207 & 489 & 5733 & -27.5 & 13.97 & 1.1 & 12.9 & -29.18 & 15.05 & 13.9 \\
\hline 208 & 493 & 5791 & -28.1 & & & & & & \\
\hline 210 & 497 & 5849 & -30.5 & 17.04 & 1.3 & 13.5 & & & \\
\hline 211 & 500 & 5885 & -30.4 & & & & & & \\
\hline 215 & 509 & 6024 & -29.7 & 14.85 & 1.1 & 13.3 & -31.24 & 17.44 & 15.6 \\
\hline 217 & 514 & 6090 & -30.5 & & & & & & \\
\hline 218 & 516 & 6132 & -32.2 & 17.13 & 1.2 & 13.8 & & & \\
\hline 221 & 522 & 6221 & -31.2 & 17.96 & 1.3 & 13.9 & -32.20 & 21.06 & 16.3 \\
\hline 223 & 527 & 6292 & -30.7 & & & & & & \\
\hline 224 & 529 & 6323 & -31.3 & & & & & & \\
\hline 226 & 534 & 6386 & -31.5 & 17.93 & 1.3 & 13.6 & -32.45 & 21.42 & 16.2 \\
\hline 227 & 536 & 6424 & -25.1 & & & & & & \\
\hline 228 & 539 & 6467 & -31.1 & 17.69 & 1.3 & 13.8 & & & \\
\hline 230 & 545 & 6565 & -31.0 & & & & & & \\
\hline 231 & 547 & 6594 & -30.9 & 17.82 & 1.2 & 14.5 & & & \\
\hline 232 & 550 & 6627 & -30.4 & & & & & & \\
\hline 234 & 554 & 6694 & -31.0 & 16.1 & 1.1 & 15.3 & & & \\
\hline 236 & 558 & 6757 & -31.5 & & & & & & \\
\hline 237 & 560 & 6790 & -30.8 & 10.61 & 0.8 & 14.1 & & & \\
\hline 239 & 564 & 6851 & -31.4 & 16.7 & 1.1 & 15.2 & & & \\
\hline 242 & 571 & 6949 & -29.0 & 13.19 & 0.9 & 14.3 & & & \\
\hline 244 & 575 & 7009 & -29.4 & 17.1 & 1.1 & 15.3 & & & \\
\hline 245 & 576 & 7035 & -27.0 & 16.4 & & & -30.94 & 17.49 & \\
\hline 246 & 578 & 7068 & -27.1 & & & & & & \\
\hline 247 & 581 & 7102 & -29.6 & 17.2 & 1.2 & 14.7 & -31.07 & 19.11 & 16.3 \\
\hline 250 & 586 & 7190 & -32.0 & 21.5 & 1.4 & 15.3 & -32.14 & 22.88 & 16.3 \\
\hline 251 & 588 & 7221 & -31.7 & & & & & & \\
\hline
\end{tabular}



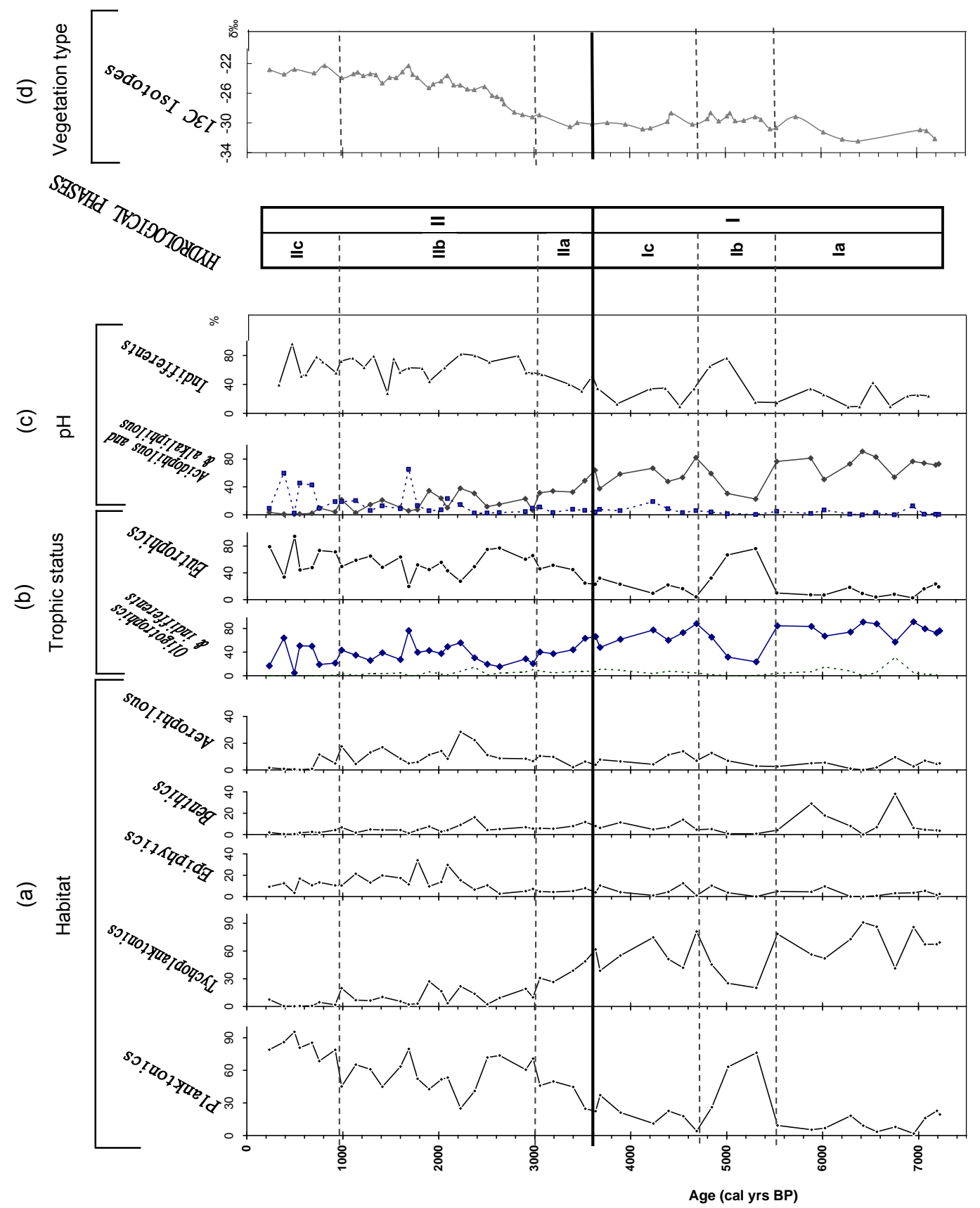

Fig. 7. Variations of habitat (a), trophic status (b) and pH (c) groups over the core. Habitat: Planktonics, Tychoplanktonics, Epiphytics, Benthics and Aerophilous. Trophic status: Oligotrophics strong line, indifferent (dotted line) and eutrophic taxa. pH: Acidophilic (strong line), Alkaliphilic (dotted line) and $\mathrm{pH}$-indifferent taxa. Modifications of vegetation type over the core (d).

processes leading to isotopic disequilibrium of the lacustrine carbonate system. However, the organic carbon content shift observed by Ngos and Giresse (2011) and our $\mathrm{C}_{\text {ORG }}$ and $\mathrm{C}_{\mathrm{TOT}}$ data do not support the hypothesis of a greater lacustrine productivity though eutrophic and planktonic algae show and increase. According to the analysis of literature results examining the complete range of $\delta^{13} \mathrm{C}$ of benthic and planktonic algae on a global basis, France (1995) shows that freshwater benthic algae exhibit $\delta^{13} \mathrm{C}$ values of $-26 \pm 3 \%$ o and phytoplankton of $-32 \pm 3 \%$, an average difference of about $6 \%$. Thus assuming that this is true for diatoms of Lake Mbalang we compared the peaks of abundance of benthic and planktonic diatoms (Fig. $6 \mathrm{~g}$ and $\mathrm{b}$ ) of M4 core to the $\delta^{13} \mathrm{C}_{\mathrm{ORG}}$. We did not find covariations with benthic diatoms. 
The two main peaks of benthic diatom abundances $(>30 \%$ at $557 \mathrm{~cm}$ and $498 \mathrm{~cm}$ ) observed at the base of M4 core are not correlated to enriched carbon isotope ratios $(<-28 \%$, Table 2) and along the M4 core planktonic diatoms increase (decrease) when $\delta^{13} \mathrm{C}_{\mathrm{ORG}}$ increases (decreases). These inverse covariations suggest that planktonic and benthic diatoms are not the main sedimentary carbon source.

We cannot exclude that enriched values from 3400 calyr BP onwards may also reflect a mixture of terrestrial and freshwater organic matter. However we suggest that $\mathrm{C}_{\mathrm{ORG}}$. $\mathrm{N}_{\mathrm{TOT}}$ ratios and carbon stable isotope ratios of M4 core may well be indicators of vegetation cover of the Lake Mbalang watershed. Abundance of the tychoplanktonic diatoms showed also an inverse covariation with the $\delta^{13} \mathrm{C}_{\mathrm{ORG}}$ (Fig. 6a and c) though the two proxies show differences when compared in details. $\mathrm{C}_{\mathrm{ORG}} / \mathrm{N}_{\mathrm{TOT}}$ and $\delta^{13} \mathrm{C}_{\mathrm{ORG}}$ are negatively correlated along the M4 core (Fig. 3h). This covariation is not a sign of post depositional changes of the original isotopic characteristics of the primary organic matter but we will show thanks to this multi-proxy study that the concomitant increase of the $\delta^{13} \mathrm{C}_{\mathrm{ORG}}$ and Poaceae pollen evolution (Vincens et al., 2010) together with a decrease of the $\mathrm{C}_{\mathrm{ORG}} / \mathrm{N}_{\mathrm{TOT}}$ ratios can be interpreted in terms of paleolimnological and paleovegetation variations forced by climatic changes.

\subsection{Phase I: between 7200 and 3500 cal yr BP}

The diatom flora of the lake was dominated by the oligotrophic, acidophilous tychoplanktonic diatoms represented essentially by Aulacoseira distans var. humilis and A. distans var. Africana. These taxa were reported in several tropical swamps and swampy lakes from East Africa as Lake Kioga (Uganda) and in the swamps of Bangweulu (Zambia). In Lake Kioga (altitude $1036 \mathrm{~m}$ ) they can represent up to $75 \%$ of the plankton samples (Gasse, 1986). From the study of the modern diatom and associated water characteristics of Saharan/Sahelian waterbodies, they were encountered in cold stratified water conditions (Gasse, 1987) although they generally prefer warm water conditions (Gasse, 1986). High percentages (40-80\%) of these taxa are encountered in the modern data set of Adamawa in bottom mud of lake borders occupied by aquatic vegetation. In swampy locations, dominated by sedges and Poaceae, their abundance was relatively high $(28 \%)$ (Kom, 2010). We thus inferred that these species are characteristics of low to high water depth and stable water table that can be occupied by aquatic vegetation or not. They also indicate oligotrophic and acidophilous waters.

From 7200 to 5500 calyr BP (subphase Ia): high abundance of tychoplanktonic species Aulacoseira distans var. humilis and A. distans var. africana (41-91\%) suggest a generally acidic, oligotrophic and relatively stable or less mixed water table. Alkaliphilous tychoplanktonic taxa $(C y$ clotella ocellata and C. meneghiniana) remained consistently low except at the end of the subphase. Planktonic diatoms represented mainly by $A$. muzzanensis were also present but exhibit relatively low abundance; their highest abundance in this sub-phase is observed between 7200 and 6300 cal yr BP (18-23\%). A muzzanensis is considered as an eutrophic (Hustedt, 1927-1966; Cholnoky, 1968), planktonic taxa (Shoeman, 1973), encountered in the plankton of lakes and great rivers (Hustedt, 1930; Krammer and LangeBertalot, 1991) but it can also occur in some lakes in shallow turbid waters. Their presence can thus be interpreted in this sub-phase as a result of relatively high water depth and more mixed eutrophic water table, conditions that can be observed during the dry season when the north-eastern dry winds are preponderant. Hence, we can infer from the two previous groups during this subphase, a generally moderate to high lake level that can be mixed episodically. Benthic diatoms represented mainly by Stauroneis phoenicenteron, S. anceps var. gracilis and Pinnularia viridiformis were more important in this subphase, they peaked between 6900 and $6600 \mathrm{cal} \mathrm{yr}$ BP (up to $38 \%$ ) and at $6300-5900 \mathrm{cal} \mathrm{yr} \mathrm{BP} \mathrm{(up}$ to $29 \%$ ); their high abundance suggests periods of clearer water column or at least episodic lowering of lake level. The hypothesis of lake level lowering is also suggested by the presence of sand in the lowermost part of the core along with abundant phytoliths and spicules but the low abundance of epiphytic diatom taxa excluded a very low lake level where the lake basin could have been occupied by dense macrophytic vegetation. $\delta^{13} \mathrm{C}_{\mathrm{ORG}}$. values are low with a mean value of $-31.2 \pm 1.1 \%$ o consistent with a $\mathrm{C} 3$-dominated terrestrial flora. Some very low $\delta^{13} \mathrm{C}_{\mathrm{ORG}}$. values $(-32.5 \%$ o $)$ may also be due to the presence of plant material influenced by the isotopic effects of a dense, closed canopy forest that developed at that time. This phase is also characterized by $\delta^{13} \mathrm{C}_{\text {TOT }}$ shifts towards higher values: One peak $(-27.1 \%$ ) covaries with one of the major sand layer evidence described at $580-560 \mathrm{~cm}$ and the two other peaks at 508 and $534-535 \mathrm{~cm}(\sim-25 \%$ and $-27 \%$, respectively) covarying with the Phytoliths/Diatoms and Spicules/Diatoms ratios (Fig. 3). After acid treatment, the peaks disappeared suggesting siderite influences the total sedimentary carbon isotopic ratios. These results and the absence of covariation with the benthic diatoms reinforced the hypothesis of episodic lowering of lake level and the presence or the vicinity of the aquatic vegetation and important terrestrial organic matter input as supported by Ngos et al. (2008) and Ngos and Giresse (2011). Though epiphytic diatom abundance (Amphora ovalis, Cocconeis placentula and varieties and Gomphonema gracile) remained consistently low, the hypothesis is nevertheless supported also by high values of total organic carbon (Ngos et al., 2008). The mean $\mathrm{C}_{\mathrm{ORG}} \cdot / \mathrm{N}_{\mathrm{TOT}}$. ratio is $15.8 \pm 1.0$.

From 5500 to 4800 calyr BP (subphase Ib): planktonic diatoms represented mainly by $A$. muzzanensis increased markedly and reached $63-76 \%$ abundance while tychoplanktonic diatoms decreased. This suggests an increase of lake level and/or a well mixed water table. Benthic and 
Table 3. $\mathrm{C} / \mathrm{N}$ ratios and $\delta^{13} \mathrm{C}$ of modern soils sampled in the Ombella-Mpoko and Lobaye provinces of Central African Republic (see the sampling field design in Aleman et al., 2011). These data were obtained in the frame of the ANR - ERA Net BIODIVERSA COFORCHANGE Project. The region is a rainforest progressively giving way to savannas, on ferralsols under a typical tropical climate consisting in an alternation of a dry season from November to February followed by a 8-months long wet season, with about $1500 \mathrm{~mm}$ annual precipitation (Bangui weather station, FAOCLIM, 2005).

\begin{tabular}{lll}
\hline $\begin{array}{l}\text { Sample } \\
\text { Number }\end{array}$ & ${ }^{13} \mathrm{C}_{\mathrm{Bulk}}$ & $\mathrm{C}_{\text {Tot. }} / \mathrm{N}_{\text {Tot. }}$ \\
\hline 1 & -18.1 & 16.0 \\
2 & -18.2 & 16.6 \\
3 & -17.7 & 15.7 \\
4 & -18.6 & 15.2 \\
5 & -15.8 & 14.7 \\
6 & -17.8 & 17.5 \\
7 & -18.1 & 17.0 \\
8 & -18.6 & 18.1 \\
9 & -25.7 & 14.2 \\
10 & -24.7 & 14.0 \\
11 & -19.0 & 19.3 \\
12 & -18.1 & \\
13 & -16.8 & \\
14 & -23.0 & 15.3 \\
15 & -26.7 & 12.1 \\
16 & -27.2 & 12.2 \\
17 & -27.6 & 10.1 \\
18 & -28.3 & \\
\hline
\end{tabular}

epiphytic diatoms nearly disappeared; aerophilous taxa (Eunotia incisa and E. pectinalis) exhibit very low abundance $(\sim 3 \%)$. The $\delta^{13} \mathrm{C}_{\text {ORG. values vary from }-30.8 \text { to }-28.7 \% \text { o }}$ between $470 \mathrm{~cm}$ and $423 \mathrm{~cm}$. The mean $\delta^{13} \mathrm{C}_{\mathrm{ORG}}$ value for this period is $-29.5 \pm 0.7 \%$ and the mean $\mathrm{C}_{\mathrm{ORG}} . / \mathrm{N}_{\mathrm{TOT}}$. ratio is $15.3 \pm 1.4$. At those levels, we also noticed the effect of carbonate siderite on the stable isotopic composition of the total carbon. This episode of slight increase of $\delta^{13} \mathrm{C}_{\mathrm{ORG}}$. compared with the previous period may be related to a slightly higher photosynthetic activity of eutrophic algae (Hollander and McKenzie, 1991; Law et al., 1995) and/or Poaceae taxa (Vincens et al., 2010). We suggest that during this time, the lake level was generally high, nevertheless, episodes of wind stress comparable to present day's dry season were longer or more severe than before. Consequently the lake experienced low level episodically, but benthic and epiphytic taxa could not develop due probably to a mixed, turbid water column. The high lake level can be explained by high and probably well distributed rainfall over the year that allowed the maintenance of forest vegetation as shown by $\delta^{13} \mathrm{C}_{\mathrm{ORG}}$. data and the presence of savanna patches.
From 4800 to 3500 cal yr BP (subphase Ic): planktonic diatoms decreased significantly, tychoplanktonic species rose (up to $75-81 \%$ ) then showed a decreasing trend with short (centennial) spells of very low abundance towards the end of the sub-phase. This may indicate a slight lowering of lake level and probably a clearer, less turbid water column also evidenced here by the increase of both benthic, epiphytic taxa (12\%) at 4500 cal yr BP and aerophilous taxa $(7-13 \%)$ at $4800-4500 \mathrm{cal}$ yr BP. This is also attested by a slight increase of spicules and phytoliths in samples which confirm the development of aquatic vegetation closer to the coring site. During this period, $\delta^{13} \mathrm{C}_{\mathrm{ORG}}$. background signature remained consistently low ( -30.8 to $-28.7 \%$ o). Mean $\delta^{13} \mathrm{C}_{\mathrm{ORG}}$ and $\mathrm{C}_{\mathrm{ORG}}$. $/ \mathrm{N}_{\mathrm{TOT}}$. ratios are $-30.1 \pm 0.7 \%$ o and $15.2 \pm 1.5$ respectively suggesting similar environmental conditions as during the previous period. However, this subphase is also characterized by the appearance of $A$. granulata var. valida, A. granulata var. tubulosa and Stephanodiscus astraea. Although these taxa are typical planktonic species, they should be interpreted with caution because in Lake Ossa area in southern Cameroon $\left(3^{\circ} 50^{\prime} \mathrm{N}, 9^{\circ} 36^{\prime} \mathrm{E}\right)$, it was shown based on their bad state of conservation, their distribution and their abundance in the lake modern sediment samples and in the uppermost layer of soils under the forest surrounding the lake, that they are originated from the Saharan diatomite deposits (Nguetsop et al., 2004). Moreover, recent analyses of modern sediments from a dried wetland (Ndjombi Swamp, near Kika SE Cameroon) revealed the presence of a comparable assemblage of taxa while other diatoms where completely absent. Hence their abundance in lake sediments was interpreted as an intensification of NE trade winds that are preponderant in Adamawa during the boreal winter rather than water depth or water trophic status changes. We can hypothesised that, the appearance of these taxa in Lake Mbalang marked as in Ossa area an intensification at least episodically of the NE trade winds.

\subsection{Phase II: between 3500 and 0 cal yr BP}

Planktonic diatoms, dominated by eutrophic A. muzzanensis indicated a high lake level and well mixed water. Tychoplanktonics declined significantly during this period and nearly disappeared. Windblown diatoms were consistently present, even if their abundance showed important fluctuations. $\quad{ }^{13} \mathrm{C}_{\mathrm{ORG}}$. values (ranging between -30.5 and $-22.3 \%$ o) increase from 3500 to $0 \mathrm{cal}$ yr BP. This increase is concomitant with the increasing proportion of $\mathrm{C} 4$ plant vegetation in the landscape cover and consequently its $\mathrm{C}_{\text {ORG }}$ contribution to the lake sediment.

From 3500 to 2800 cal yr BP (Subphase IIa): eutrophic diatoms characteristic of well mixed layer increased and reached about $70 \%$ at 2600-2500 cal yr BP. A. distans var. humilis and A. distans var. africana which are indicators of the stability of water table decreased markedly. Mean $\delta^{13} \mathrm{C}_{\mathrm{ORG}}$. values remained relatively low $(-29.5 \pm 0.7 \%$ o $)$ 
and the mean $\mathrm{C}_{\mathrm{ORG}} / \mathrm{N}_{\mathrm{TOT}}$. ratio does not change significantly $(15.1 \pm 0.9)$ suggesting that sources and proportions of organic matter have not changed yet $\mathrm{C}_{\mathrm{ORG}}$. content (mean value $11.5 \%$ ) is lower compared to previous periods. The persistence of windblown diatoms showed an intensification of windiness on the lake environment. This phase marked an unequivocal change of climatic conditions in the area; from relatively more stable or less mixed water table reflecting probably the stability of the air at low layers of the atmosphere to more mixed water table linked to a reinforced seasonality.

From 2800 to 800 cal yr BP (Subphase IIb): This phase is marked by high fluctuations in abundances of planktonic taxa at plurisecular timescale. Although A. muzzanensis dominates throughout the sub-phase, Fragilaria delicatissima became more important and peaked at $2100 \mathrm{cal} \mathrm{yr} \mathrm{BP} \mathrm{(14 \% ),}$ between 1800 and $1700 \mathrm{cal}$ yr BP (5-61\%) and between 1100 and $900 \mathrm{cal}$ yr BP (5-14\%). Contrarily to A. muzzanensis, $F$. delicatissima is considered as an oligotrophic to mesotrophic taxa (Kammer and Lange-Bertalot, 1991). Lowest abundances of planktonics are observed at 2400 2200 cal yr BP, 1900, 1400 and 1000 cal yr BP. In these levels, the epiphytic (Gomphonema. gracile, Amphora ovalis, Cocconeis placentula and its variety lineata) and aerophilous (Eunotia incisa and E. pectinalis var. minor) diatoms increased, indicating a lowering of the lake level at least at seasonal or interannual timescales. The relatively high abundance of windblown diatoms indicated the maintenance of the influence of the north-eastern trade winds in the Lake Mbalang environment. The development of $F$. delicatissima when windblown diatoms are low indicated probably a less mixed water table and/or a slight increase in lake level. This idea is reinforced by the fact that epiphytic, benthic and aerophilous taxa are very low. The sub-phase represents probably the period of time during which short time maximum climate variability occurred. This variability is roughly reflected on $\delta^{13} \mathrm{C}_{\mathrm{ORG}}$. with fluctuation of $\sim 2 \%$ amplitude and even smaller after 1500 cal yr BP $(-24.6$ to $-22.3 \%$ ).

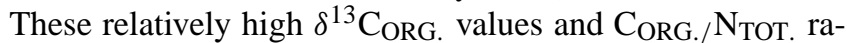
tios (varying between 10.5 and 14.4 ; mean value $12.4 \pm 0.9$ ) suggest yet terrestrial organic matter input suggesting the maintenance of $\mathrm{C} 4$ plants in Lake Mbalang environment. Very high biological activity of eutrophic algae may be responsible of such enriched $\delta^{13} \mathrm{C}_{\mathrm{ORG}}$. however, the decreasing $\mathrm{C}_{\text {ORG. }}$ trend along the core does not support this hypothesis.

From 800 to 0 calyr BP (Subphase IIc): high abundance of planktonics indicates a persistence of high lake level. The two main planktonic species alternated at this level, the change from Aulocoseira to Fragilaria dominated assemblage in diatom community is interpreted as the changing to more clear water column or shallowing, reduced mixing when P:E is low (Stager and Anfang-Sutter, 1999). The substantial decrease of windblown taxa supports the inference for more stable water column. This may also indicates important changes in water trophic status. Among other taxa,
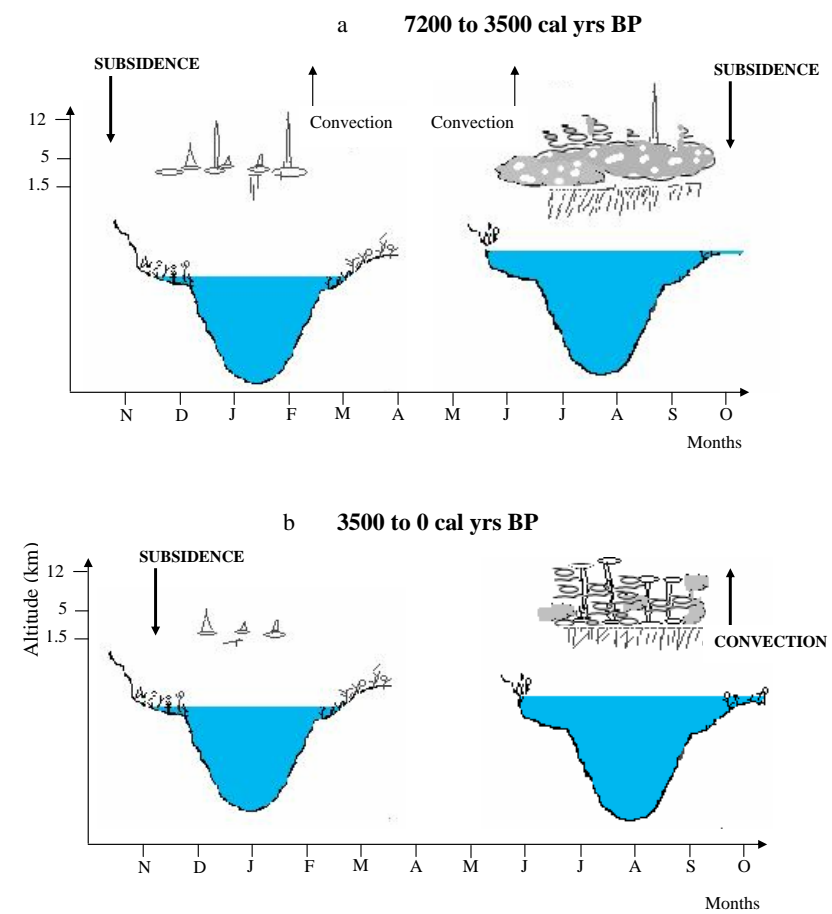

Fig. 8. Sketch of atmospheric features (clouds cover and air movement) and relative modifications of Lake Mbalang level, in the dry season (January) and rainy season (August) before 3500 cal yr BP (a) and afterwards (b). Before 3500 cal yr BP, stratiform cloud cover were abundant, convective cloud are dominant after 3600 cal yr BP.

only Gomphonema gracile, Cocconeis placentula and its variety lineata remained present with percentages close to those of the precedent zone. The $\delta^{13} \mathrm{C}_{\mathrm{ORG}}$. values and $\mathrm{C}_{\mathrm{ORG}} / \mathrm{N}_{\mathrm{TOT}}$ ratios were similar to the end of the previous sub-phase suggesting yet the maintenance of $\mathrm{C} 4$ plants.

\section{Discussion}

The variations of the abundances of planktonic and tychoplanktonics can be considered as indicators of lake level changes (Fig. 9a), although the curve should be interpreted with caution because these organisms can also thrive in large free water surface. Acidophilous oligotrophic and tychoplanktonic Aulacoseira distans var. humilis, A. distans var. africana and planktonic taxa Fragilaria delicatissima are characteristic of stable or less mixed water table, which presupposes also a relatively stable air layer over the lake. During the boreal summer, a deep atmospheric convection (zone $\mathrm{C}$ of the cross-section of the troposphere over tropical Africa (after Leroux, 1970, 2001), entails heavy rains that directly cool waters of the surface. In these conditions also characterised by heavy clouds and subsequent reduced solar radiation inputs, thermal differences between epilimnion and hypolimnion are reduced and finally mixing occurred. 


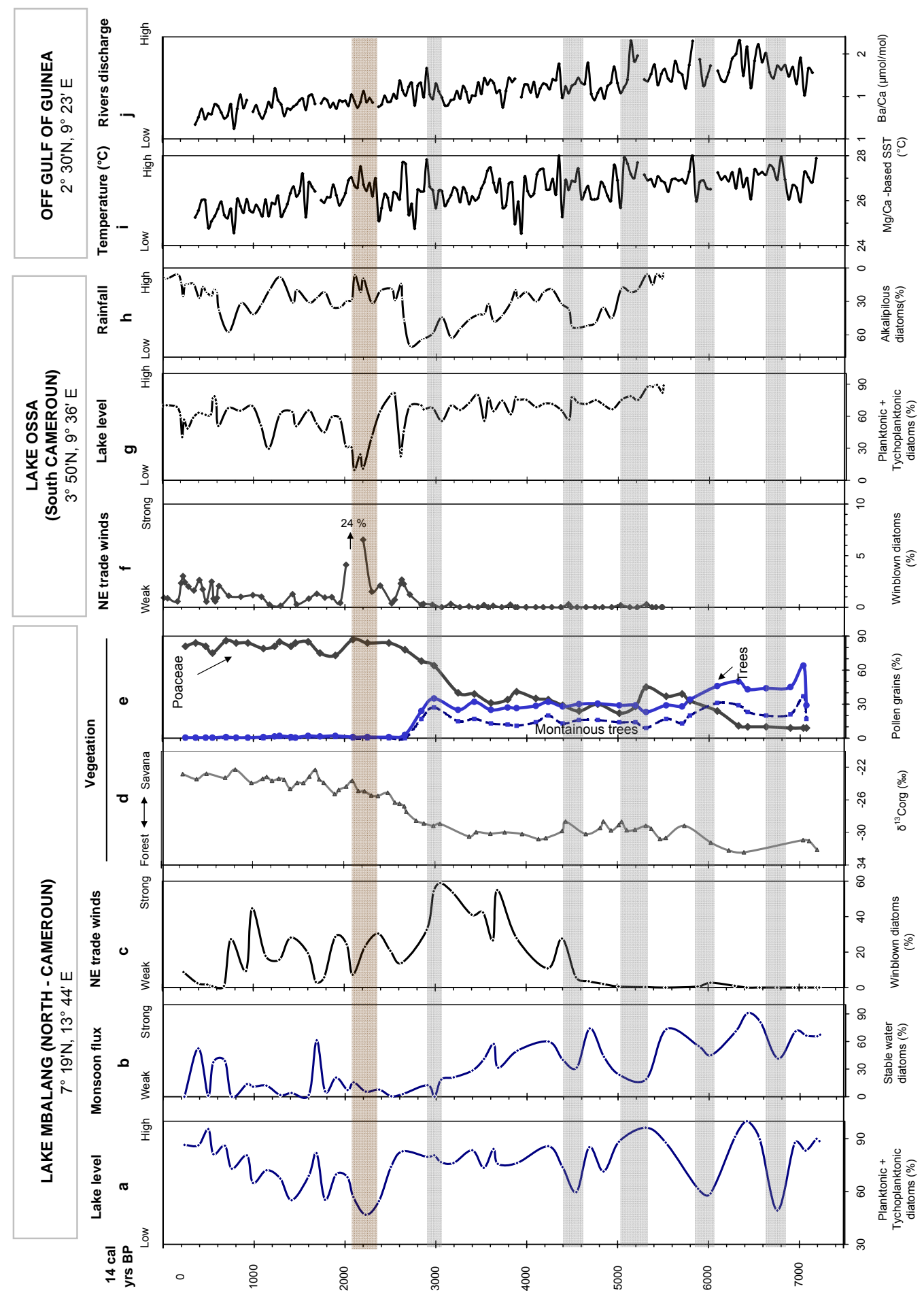

Fig. 9. Comparisons between Lake Mbalang (North-Cameroon), Lake Ossa (South-West Cameroon) and Gulf of Guinea. Lake Mbalang level variations evidenced by relative abundance of Planktonics + Tychoplanktonics (a), Monsoon flux intensity reflected by stable water diatoms, higher percentages correspond to more intense monsoon flux (b), NE trade winds (Harmattan) intensity, higher allochtonous diatom abundance indicates more intense Harmattan (c). Changes from C3 to C4 dominant plants in vegetation is evidenced by $\delta^{13} \mathrm{C}$ of sedimentary organic matter (d), also shown by palynological data (e) (Vincens et al., 2010). Variations in NE trade winds (Harmattan) (f) and lake level (g) are shown in Lake Ossa as well as relative change in rainfall evidenced from alkaliphilous diatoms (h) (Nguetsop et al., 2004). Variations in temperature off Gulf of Guinea is shown from $\mathrm{Mg} / \mathrm{Ca}$ based SST (i), Rivers discharge based on ration Ba/Ca is also shown (j) (Weldeab et al., 2005, 2007). 
However, if in the past the convective zone moved farther north than today, the Adamawa plateau could have been subjected to a climate that is described by Leroux in zone D where subsiding air masses present at mid-levels of the atmosphere generate stability at low levels. Consequently, the weather is cloudy and rainfall strongly reduced in the form of light rain and drizzle. In these conditions, evaporative heat loss may be suppressed or reduced, and surface warming during this period of low wind stress is likely to cause more stability in the water column (Kling, 1987). Hence, high abundance of the two species in the past can suggest conditions close to those observed in the boreal summer when the ITCZ is farther north, which entail the stability of the water column and/or the development of aquatic vegetation. Conversely, the planktonic Aulacoseira muzzanensis and Aulacoseira granulata thrive better in well mixed water tables that are associated to high temperatures, intense storms and windiness. These conditions are observed nowadays, mostly during the boreal winter in the Adamawa plateau and entail a deeper and unique thermocline in the water table (Kling, 1987). Such large diatoms have also been used as indicators of water table mixing in east African lakes (Stager et al., 1997). The variations in the intensity of the NE trade winds are inferred, as in Lake Ossa, from relative abundance of windblown diatoms (Fig. 9c). We suggest that the mixing is mostly due to the intensification of the north-eastern trade winds (Harmattan) during the year, although crater lakes of the Cameroon volcanic line show high volume/surface ratios and are relatively sheltered from winds.

Paleoclimatic data suggest that tropical Africa experienced during the Holocene important paleoclimatic changes that are now well dated (Servant et Servant-Vildary, 1980; Gasse, 2000). The base of the core M4 (7200 cal yr BP) belongs to the African humid phase that is documented in several continental sites (e.g. Gasse, 2000; Talbot and Johanessen, 1992; Stager et al., 1997) and marine sites offshore Africa.

\subsection{Middle to late Holocene: from 7200 to 3600 cal yr BP}

Diatoms data of Lake Mbalang inferred a stable water table that may indicate a stronger monsoon flow. These data are consistent with appearance of mountain forest taxa pollens in the palynological spectrum. The two most abundant taxa Olea capensis and Podocarpus sp were probably developed on nearby mountains that are today covered by shrubby savannas dominated by Hymenodictyon floribundus (Vincens et al., 2010). The nearest modern ecological niche of these two taxa according to Letouzey $(1968,1985)$ is located at Mount Ngan-Ha (1923 m), some $35 \mathrm{~km}$ east of Lake Mbalang. These species are also present some $300 \mathrm{~km}$ north of the lake at Mount Poli $\left(7^{\circ} 50^{\prime} \mathrm{N} ; 2049 \mathrm{~m}\right)$ and at Tchabal Mbabo highlands $\left(7^{\circ} 18^{\prime} \mathrm{N}, 2460 \mathrm{~m}\right)$ located $165 \mathrm{~km}$ west of Ngaoundere on the Cameroon volcanic line. In fossil records, O. capensis and/or Podocarpus sp. occurrences in several locations in the northern subtropics and subequatorial areas of Africa (Salzmann et al., 2002) and especially during the Last Glacial Maximum were interpreted as indicative of cooler air conditions during a longer period of the year linked to stratiform cloud cover that are observed today only during the boreal summer when upwelling system is reinforced off the Gulf of Guinea (Maley and Brenac, 1998). But this hypothesis is less likely during the Holocene because marine isotopic data off the Gulf of Guinea showed no evidence of past strong upwellings system at that area (Weldeab et al., $2005,2007)$. Another alternative is to consider episodic cold air mass advections of middle and high latitudes that can also contribute to such air conditions, but the weakness of this hypothesis is shown by the absence of such occurrences in the Saharan/Sahelian regions during this period (Servant and Servant-Vildary, 1980). If the climatic determinism is the same as today, their abundance in Adamawa fossil spectra should imply a northward displacement of ecological boundaries as shown by palynological data (Watrin et al., 2009; Lezine, 2009) and reproduced by vegetation models (Hély et al., 2009). Diatoms in Lake Mbalang inferred a moderate to high lake level which can correspond to precipitation lower than today in a context of low evaporation because of the far northern position of the ITCZ, but precipitation distribution remained favourable for forest development as shown by palynological and $\delta^{13} \mathrm{C}_{\mathrm{ORG}}$. data. Although sponge spicules and phytopliths were relatively abundant, low epiphytic and benthic diatoms abundance showed that water level was not strongly reduced. It is possible that these phytoliths were from a more important belt than today of ligneous tree fringing the lake (Alchornea sp.) during this period of relative low evaporation and high water content in soils as is observed in other sites of central Africa (Ngomanda et al., 2009b).

From $7200 \mathrm{cal}$ yr BP onwards, the decreasing trend of diatoms characterising the stable water column is punctuated by several abrupt low abundance at 6700, 5800-6000, 50005300,4500 and 3600 cal yr BP (Fig. 9b) corresponding probably to episodes of weaker monsoon flux superimposed on the general trend, showing the complexity of climate change towards late the Holocene drier conditions. This pattern is reflected in water balance and vegetation landscape in several areas of tropical Africa and was largely discussed to underline the timing and magnitude of climate change from one region to another and associated climatic mechanisms (Gasse, 2000). The abrupt dryness of the climate corresponding to the end of the African Humid Period (AHP) shown by marine data off Mauritania (de Menocal et al., 2000; Adkins et al., 2006) is close to $5000-5300 \mathrm{cal} \mathrm{yr} \mathrm{BP}(420-470 \mathrm{~cm})$ low spell of tychoplanktonics observed in Lake Mbalang (Fig. 9b). This event is interpreted in Lake Mbalang as a period of increased mixing of the water table forced probably by north-eastern trade winds of the dry season. Therefore, the more development of Poaceae in Lake Mbalang area at that time can be explained by increased seasonality with a longer dry season compared to the previous period rather 
than an absolute decrease of rainfall as suggested by Vincens et al. (2010). Lake Ossa located south of Adamawa $\left(3^{\circ} 50^{\prime} \mathrm{N}\right)$ experienced convective rainfall in agreement with our model (Fig. 9h).

The spell dated at 4500-4000 cal yr BP corresponds probably to the most documented climatic phase throughout Africa; it was recorded at several sites of both southern and northern tropics (Servant and Servant-Vildary, 1980; Gasse, 2000). Drier conditions are also registered both by palynological, limnological and/or sedimentological data in subtropical latitudes of western Africa in Biu plateau $\left(12^{\circ} 32^{\prime} \mathrm{N}\right)$ and around lake Sele $\left(7^{\circ} 9^{\prime} \mathrm{N}\right.$ ) after $\sim 3800 \mathrm{yr}$ BP (Salzmann et al., 2002, 2005) with the opening of the Dahomey Gap in the rain forest belt. In sub-equatorial regions this period was marked in Lake Bosumtwi by a low lake level at about 4000 yr BP (Talbot and Delibrias, 1980) although recent data did not confirmed this low stand (Russell et al., 2003). In central African subequatorial regions, proxy data inferred important disturbances in the periphery of the equatorial rain forest belt with possible appearance of included savannas (Ngomanda et al., 2009a, b) and complete dryness of lakes as Lake Sinnda in south Congo by $4400 \mathrm{yr}$ BP (Vincens et al., 1994; Bertaux et al., 2000). In inner forest block, lakes were less affected by this climatic change (Vincens et al., 1999; Ngomanda et al., 2007; Kossoni et al., 2009). This period is characterised in Lake Mbalang by the maintenance of indicators of stable water table in agreement with the palynological and $\delta^{13} \mathrm{C}_{\mathrm{ORG}}$. data, and thus to a stronger monsoon. But the appearance of windblown diatoms $(\sim 4400$ cal yr BP) attests probably the beginning of the aridification of the Sahara and/or the intensification of the NE trade winds (Fig. 9c).

Despite the scarcity of paleoclimatic records on highlands, the Bambili (western Cameroon) core provided a $24000 \mathrm{yr}$ time series that highlighted the comprehension of paleoclimatic evolution around the Gulf of Guinea. Contrarily to lowlands, Lake Bambili registered a dramatic low lake level from 10000 to $7000 \mathrm{cal} \mathrm{yr} \mathrm{BP,} \mathrm{then} \mathrm{fluctuated} \mathrm{around}$ this low value afterwards (Stager and Anfang-Sutter, 1999) while other sites of tropical Africa underwent the so called "African humid period". In Lake Njupi located north of Bambili at $1020 \mathrm{~m}$ altitude, Olea. capensis and Podocarpus sp. were present until around $3000 \mathrm{yr} \mathrm{BP}$, suggesting a comparable evolution as the Adamawa plateau. Thus highlands as Bambili (2264 $\mathrm{m}$ altitude) may probably have evolved differently during greater part of the Holocene in term of water balance as suggested by Stager and AnfangSutter (1999), however synchronous evolutions between lowlands and highlands seems to have started at 3000 cal yr BP. Lake Mbalang evolved like lowlands in term of the pattern of change even though the palynological and hydrological signals seem to have been also controlled by altitudinal and meridian variations of climatic factors. It is thus possible that lowlands and highlands below $1200 \mathrm{~m}$ altitude like the Adamawa plateau were under conditions characterised by an important cloud cover during a greater part of the year while highlands such as Bambili were submitted to drier climate over the year.

\subsection{The Late Holocene (last 3600 cal yr BP)}

After $3600 \mathrm{cal}$ yr BP, diatoms and other proxies of Lake Mbalang inferred significant changes of the climatic conditions. High abundance of A. muzzanensis and A. granulata suggest a more mixed water layer and a deeper thermocline. These conditions prevail today during the boreal winter. The lake level remained relatively high after $3000 \mathrm{cal} \mathrm{yr}$ and decreased between 2400-2100 cal yr BP. The other relative lowstands are dated at 1800 and 1400 cal yr BP, time after which the lake started its evolution towards present day's high level (Fig. 9a). The windblown diatoms remained relatively important consistent with a significant influence of the NE trade winds during the year responsible of a well mixed water table. Nevertheless, the diatom derived lake depth reflects limnological variations and consequently water balance at centennial to millennial timescales. The relatively higher abundance of epiphytic, benthic and aerophilous mixed with planktonic and tychoplanktonic diatoms in individual samples reflects the lowering of lake level at the interval of time represented by one sample $(\sim 6 \mathrm{yr})$ or could reflect seasonal variability. In that case, one can hypothesise in such climatic conditions the development of planktonic diatoms during the rainy season high lake level and development of littoral forms during the dry season at the lake borders on Cyperaceae (sedges) that fringe the lake today. But this short term variability did not strongly affect the vegetation cover: among minor changes we noticed a depletion of the $\delta^{13} \mathrm{C}_{\mathrm{ORG}}$. values (Fig. 9d), concomitant to a slight decrease of the Poaceae at 1800 and 1400 cal yr BP (fig 9e). Palynological data in Lake Mbalang showed the expansion of Poaceae at 3000 cal yr BP, they remained the most abundant than any other groups of plants until the present days. Sedges also developed and reached their highest abundance suggesting the lowering of lake level at a short timescale. Montane forest regrowth (Fig. 9e), and arboreal savannas taxa abundance became very low. These modifications in the vegetation landscape implied a more dry and contrasted climate (Vincens et al., 2010) as also suggested by diatom habitat groups and windblown diatoms (Fig. 9c). The 24002100 cal yr BP event is also well marked in other sites of the subequatorial regions of central Africa (Vincens et al., 1999). The data confirmed a more dry climate in southern Congo, but at the latitude of Lake Ossa, woody pioneer heliophilous taxa appear in the rain forest (Reynaud-Farrera et al., 1996), probably as a result of stormy rainfall rather than absolute low precipitation (Nguetsop et al., 2004) as well as in Nyabessan located $200 \mathrm{~km}$ south of Lake Ossa (Ngomanda et al., 2009b). In Lake Bosumtwi ( $\left.6^{\circ} 30^{\prime} \mathrm{N} ; 1^{\circ} 25^{\prime} \mathrm{E}\right)$, sedimentological records showed an evolution towards aridity and more seasonality at about $3000 \mathrm{yr}$ BP (Russell et al., 2003; 
Talbot et Johannessen, 1992). The reduction of the mixing at $1700,700-600$ and at 400 cal yr BP is marked by a slight decrease of Poaceae and the increase of Cyperaceae, $\delta^{13} \mathrm{C}_{\mathrm{ORG}}$. values decreased also slightly. This last event shows the sensitivity of vegetation and hydrology to recent centennial climate variability as it was demonstrated by Ngomanda et al. $(2007,2009 b)$.

\subsection{Paleoclimatic interpretation}

Diatoms data suggest a decreasing trend of the monsoon flux in Adamawa area from mid-Holocene ( 7200 cal yr BP) to mid-late Holocene, consistently with the decreasing summer insolation in the Northern Hemisphere and correlatively reducing land-ocean contrast linked to orbital changes. Although orbital changes account for a greater part in explaining the hydrological changes (Kutzbach and Street-Perrot, 1985), they induced regional atmospheric factors that may be useful in understanding the response of the local hydrological system. The better comprehension of climatic changes in central Africa regions around the Gulf of Guinea should integrate the structure of the atmosphere during the wet season when the monsoon flux overrides the NE trade winds in the northern summer. According to Leroux (1970, 2001), five climatic zones can be individualized in the meridian structure of the troposphere at this period of the year, they have been used in interpreting past climatic conditions by several authors (e.g. Nguetsop et al., 2004; Ngomanda et al., 2009b). The compression and dilatation of these climatic zones over the year can explain a series of climatic conditions that are encountered yearly today between $20^{\circ} \mathrm{N}$ and $5^{\circ} \mathrm{S}$. One can then hypothesize that, if in the past the rain belt moved northwards and entailed rainfall at Saharan region at around $6000 \mathrm{yr}$ BP as shown by paleoclimatic data (e.g. Gasse, 2000) and reproduced by paleoclimatic models (Kutzbach and Street-Perrot, 1985; Kutzbach and Guetter, 1986) it is likely that all the climatic zones that are linked to the strengthening of the monsoon, and not only the convection area, were more extended than today during the boreal summer. This hypothesis is reinforced by the fact that cloud cover and low evaporation that are limited today between $5^{\circ} \mathrm{S}$ and $4^{\circ} \mathrm{N}$ are also reproduced by climatic model in higher latitude at $6000 \mathrm{yr}$ BP (Kutzbach and Guetter, 1986).

From 7200-3600 cal yr BP, the lake level was mostly moderate to high as evidenced by planktonic diatoms and the water column generally stable. We suggest that the ITCZ mean position at that time was north of the Adamawa plateau (Fig. 2b) in agreement with paleoclimatic data (Gasse and Van Campo, 1994); this position entailed at the latitude of the studied lake, stratiform cloud cover and low precipitation (Fig. 8a). Temperatures were consequently relatively low due primarily to these atmospheric features, but also, to the relatively high altitude of the Adamawa plateau $(1100-1200 \mathrm{~m})$. These conditions were favourable for the development of the mountain forest taxa in the vegetation landscape and the regrowth at the forest borders (Vincens et al., 2010). This period was characterized by very low mixing except between 5000-5300 cal yr BP; the Harmattan was probably very weak until 4500 cal yr BP.

From 7200-6900 cal yr BP, diatoms data suggest a relatively deep and stable lake. Despite the age uncertainties offset and the different time resolution in published data, this subphase could correspond to the wet episode that is well known in Saharan and Sahelian regions (Servant et ServantVildary, 1980; Gasse, 2000), the African Humid period. The high monsoon inflow suggested by diatoms at 6400,5500 , 4600 and 4200 cal yr BP and characterized by relatively high lake level in Adamawa plateau (Fig. 9a) appeared at certain periods of time to be uncorrelated with data of sea surface temperatures (Fig. 9i) and rivers discharges (Fig. 9j) off the Gulf of Guinea (Weldeab et al., 2005, 2007). This can be explained if the variability of the mean position of the ITCZ is considered at multi-secular to millennial timescale as it is observed today over the year. Consistent northernmost mean position of the ITCZ may have favoured rainfall at the northern part of the catchments of Niger River while the southern part and probably a great part of the Sanaga and Ntem may have been under stable air layers (Fig. 2b). Conversely, the southernmost mean position of ITCZ may have favoured high rainfall around the Gulf of Guinea in the greatest part of the Sanaga and Ntem river catchments, and drier conditions in the upper part of the Niger River. These rivers discharge off the Gulf of Guinea may thus be very variable depending on SSTs and the position of ITCZ which strongly influences precipitation and evaporation on the continent. Lake Ossa high lake levels are observed in the context of low rainfall between 4800 and 4400 cal yr BP suggesting a climate with low evaporation and low rainfall consistent with the northernmost position of the ITCZ. Hence, the apparent discrepancies observed between rainfall on the continent, SSTs and rivers discharges off the Gulf of Guinea during Middle to Late Holocene (Weldeab et al., 2005, 2007) could be explained by these meridian changes of the structure of the lower levels of the atmosphere at centennial to millennial timescales.

The low monsoon inflows at 6700, 6000-5800 and 4600 4400 cal yr BP are also characterised by relatively low lake levels in Lake Mbalang. SSTs are low to medium except at $6700 \mathrm{cal} \mathrm{yr}$ BP where they are high. The general conditions suggest a position of the ITCZ further north than today, but brief low lake levels could indicate at least the ITCZ episodic southward displacements entailing either low rainfall (if the ITCZ moves south of Adamawa) or high rainfall (if the Adamawa region is included in the convection zone) and high evaporation in the two cases (Fig. 8b). The appearance of windblown diatoms in Adamawa at $4500 \mathrm{cal} \mathrm{yr} \mathrm{BP}$ corresponds probably to the desiccation of the Sahara or intensification of the NE trade winds. At 5300-5000, lake levels are high in Adamawa, SSTs and river discharges are high, rainfall is high in low latitude (Lake Ossa), suggesting 
the displacement towards the south of the ITCZ at a position favourable to convective rainfall in the two regions. This phase is probably contemporaneous of the onset of a dry episode in Sahara; paleolakes retreated around $5800 \mathrm{yr}$ BP (Vernet, 1995; Servant and Servant-Vildary, 1980) consistently with the termination of the African humid period (de Menocal, 2001). At that time, high mixing as observed at the upper part of the studied core (after 3600 cal yr BP) shows that position of the ITCZ was closed to its modern position (Fig. 2a). This hypothesis is reinforced by the development of savannah in the vegetation landscape indicating as today a more contrasted climate. Between 3600 and 3000 cal yr BP, SSTs off the Gulf of Guinea alternate between moderate and low values, and river discharges were relatively low or moderate in good agreement with low rainfall in Lake Ossa but high lake level inferred in Lake Mbalang may indicated higher rainfall in Adamawa plateau linked to the displacement towards the north of the convective rain belt.

Between 3000 and 0 cal yr BP, diatom data suggest the significant reduction of the monsoon flux. The lake level remained broadly high except between 2400-2100, 1800 and 1400 cal yr BP. Although the lake did not decline dramatically, indicating that rainfall remained relatively important, the increase of savannah taxa and their maintenance until today attest a seasonality change of the rainfall distribution. The influence of the NE trade winds during the year is shown by the persistence of windblown diatoms. A low lake level registered both in Lake Mbalang and in Lake Ossa between 2400 and $2100 \mathrm{cal}$ yr BP and in others subequatorial regions of Africa coincided with higher rainfall in Ossa region and important fluctuations of SSTs off the Gulf of Guinea while the river discharges decreased gradually. It revealed the unstable position of the ITCZ and consequently the rainfall belt modifications during this southwards shift. In agreement with our model, this episode corresponds to the southernmost position of the ITCZ, at least episodically. Consequently, it entailed more arid conditions northwards as shown by intense windblown diatoms, indicating the strengthening of NE trade winds in Ossa region, stormy rainfall around the Gulf of Guinea with subsequent disturbances inside the forest block. After 2000 cal yr BP, the evolution towards present days is observed. These new conditions are roughly characterized by relatively high lake level in Lake Ossa and in the Adamawa, high rainfall in Ossa region suggesting a sharp northwards shift of the mean position of the ITCZ. Meanwhile, both river discharges and SSTs showed a decreasing trend. Brief highstand at 2000-1900 cal yr BP, lowstands at 1800 and 1400 cal yr BP attested the more intense or weakening of the monsoon inflow respectively. The reduction of the mixing at 700-600 and at 400 cal yr BP marked a slight intensification of the monsoon which is well recorded both by rainfall regime and lake level in Ossa.

Holocene short climatic events were evidenced in several sites of the monsoon domain both in Africa and Asia, the forcing factors is primarily the modifications of insolation that is modulated by sea surface temperatures and land surfaces feedback mechanisms (Gasse et Van Campo, 1994; de Menocal et al., 2000).

\section{Conclusions}

Planktonic and tychoplanktonic diatoms variation suggested that Lake Mbalang did not dry during the last 7200 cal yr BP as relative fluctuations of water level are observed. A low lake level recorded at $2400-2100 \mathrm{cal}$ yr BP is contemporaneous to a climatic event evidenced in several areas of tropical Africa, and other low lake levels are observed at 1800 and $1400 \mathrm{cal}$ yr BP, after which the lake rose to its present level. Nevertheless, diatom data showed that the lake evolved from oligotrophic stable water table before 3600 cal yr BP to mixed and eutrophic conditions afterwards, corresponding respectively to a strong monsoon flow before and a more intense north-eastern trade winds (Harmattan) after. The $\delta^{13} \mathrm{C}_{\text {ORG. }}$ data indicated the development in the landscape of more forested vegetation, also confirmed by palynological data in good agreement with the inferred climate. However, the decreasing monsoon trend was punctuated by several abrupt weakenings at $6700,5800-6000,5000-5300$, and $4500 \mathrm{cal} \mathrm{yr}$ BP. After $3000 \mathrm{cal} \mathrm{yr}$ BP, the savanna vegetation developed in the Adamawa area and has persisted until today. These climatic changes can be attributed to the modifications of the position of the Intertropical Convergence Zone (ITCZ), its northernmost position between 7200 and 3600 cal yr BP entailed at the level of the Adamawa plateau, a climate characterized by very low precipitation and also very low evaporation as is observed today during the boreal summer in the southwest of Cameroon. After 36003000 cal yr BP, the ITCZ moved southward and reached a position where convective rainfall became dominant, but its amount and/or its distribution were no longer favourable to forest development.

Acknowledgements. This work is a contribution to the Ecofit program (1993-2000) that was funded by French scientific institutions (IRD, CNRS, CEA), the program provided a long core that is used in this paper. The funding for this work was also provided by START through a grant from US National Science Foundation (GEO-0627839: "Capacity Building for Global Change"). We also thank the French National Research Agency (ANR, 2008-2948962704-33) through the ErA Net BiodivERsA CoForChange Project. We want to thank Christophe Moreau and Jean-Pascal Dumoulin of ARTEMIS AMS facility (Saclay, France) who performed some of the radiocarbon dates. F. Nguetsop benefited from a scholarship offered by the "Coopération Française (MAEE)" through the SCAC (Service de Coopération et d'Action culturelle de Yaoundé") to travel to Montpellier (France). The authors are also grateful for the three anonymous referees and the editor who helped in improving the quality of the manuscript through their comments. This is ISE-M contribution No. ISEM 2011-143

Edited by: N. Weber and T. Kiefer 


\section{References}

Adkins, J., de Menocal, P., and Eshel, G.: "The African Humid period" and the record of marine upwelling from excess ${ }^{230} \mathrm{Th}$ in Ocean Drilling Program Hole 658C, Paleoceanography, 21, PA4203, doi:10.1029/2005PA001200, 2006.

Aleman, J., Leys, B., Apema, R., Bentaleb, I., Dubois, M. A., Lamba, B., Lebamba, J., Martin, C., Ngomanda, A., Truc, L., Yangakola, J. M., Favier, C., and Bremond, L:. Reconstructing savanna tree cover from pollen, phytoliths and stable carbon isotopes, J. Vegetat. Sci., in press, 2011.

Battarbee, R. W.: Diatom analysis. In: Handbook of Holocene Palaeoecology and Palaeohydrology, edietd by: Berglund, B. E., John Wiley and Sons, 527-578, 1986.

Bachelier, G.: Carte pédologique à 1/50 000 de la zone du volcanisme récent au sud-est de Ngaoundéré, Publications IRCAM, 84, p. 27,1 carte à $1 / 50000,1957$.

Bahrig, B.: Stable isotope composition of siderite as an indicator of the paleoenvironmental history of Oil Shale lakes, Palaeogeogr. Palaeocl., 70, 139-151, 1989.

Bertaux, J., Schwartz, D., Vincens, V., Siffedine, A., Elenga, H., Mansour, M., Mariotti, A., Fournier, M., Martin, L., Wirrmann, D., and Servant, M.: Enregistrement de la phase sèche d'Afrique Centrale par spectrométrie IR dans les lacs Sinnda et Kitina (sudCongo), in: Dynamique à long terme des Ecosystèmes Forestiers Intertropicaux, edited by: Servant M. and Servant-Vildary, S., Unesco, 2000, 43-49, 2000.

Brodie, C. R. Leng, M. J., Casford, J. S. L., Kendrick, C. P., Lloyd, J. M., Yongqiang, Z., and Bird, M. I.: Evidence for bias in C and $\mathrm{N}$ concentrations and $\delta^{13} \mathrm{C}$ composition of terrestrial and aquatic organic materials due to pre-analysis acid preparation methods, Chem. Geol., 282, 67-83, 2011.

Cholnoky, B. J.: Die Ökologie der Diatomeen in Binnengewässer, edited by: Cramer, J., 699 pp., 1968.

De Menocal, P.: Cultural responses to climate change during the late Holocene, Science, 292, 667-673, 2001.

De Menocal, P., Ortiz, J., Guilderson, T., and Sarnthein M.: Coherent High-and low- latitude climate variability during the Holocene warm period, Science, 288, 2198-2202, 2000.

F.A.O.: NewLocClim. Vers. 1.10. Food and Agriculture Organisation of the United Nations, Rome, 1961-1990 climatologies based on FAO's NewLocClim data and software, 2005.

France R. L.: Carbon-13 enrichment in benthic compared to planktonic algae: foodweb implications, Mar. Ecol. Progr. Ser., 124, 307-312, 1995.

Gasse, F.: Les diatomées lacustres plio-pléistocène du Gadeb (Ethiopie), Systématique, paléoécologie, biostratigraphie, Revue Algologie, 3, 249 pp., 1980.

Gasse, F.: East African diatoms, taxonomy, ecological distribution. Bibliotheca Diatomologica, edited by: Cramer, J., in: der Gebrüder Borntraeger Vertragsbuchhandlung, Berlin-Stuttgart, 201 pp., 1986.

Gasse, F.: Diatoms for reconstructing palaeoenvironments and paleohydrology in topical semi-arid zones, Example of some lakes from Niger since 12000 BP, Hydrobiologia, 154, 127-163, 1987.

Gasse, F.: Hydrological changes in African tropics since the Last Glacial Maximum, Quat. Sci. Rev., 19, 189-211, 2000.

Gasse, F. and Van Campo, E.: Abrupt Post-glacial climate events in West Asia and North Africa monsoon domains, Earth Planet Sci. Lett., 126, 435-456, 1994.
Gasse, F., Juggins, S., and Ben Khelifa, L.: Diatom-based transfer function for inferring hydrochemical characteristics of African paleolakes, Palaeogeogr. Palaeocl., 117, 31-54, 1995.

Germain, H.: Flore des diatomées, eaux douces et saumâtres du massif Armoricain et des contrées voisines d'Europe Occidentale, Société Nouvelles des Editions Boubée, Coll., Faunes et Flores actuelles, Paris, 444 pp., 1981.

Gèze, B.: Géographie et géologie du Cameroun occidental, Mémoires Muséum National d'Histoire naturelle, XVII, 320 pp., 1943.

Hedges, J. I., Clark, W. A., Quay, P. D., Richey, J. E., Devol, A. H., and Santos, U. D. E. M.: Compositions and fluxes of particulate organic material in the Amazon River, Limnol. Oceanogr., 31, 717-738, 1986.

Hély, C., Braconnot, P. Watrin, J., and Zheng W.: Climate and Vegetation: Simulating the African humid period, C. R. Geosci., 341, 671-688, 2009.

Hollander, D. J. and McKenzie, J. A.: $\mathrm{CO}_{2}$ control on carbonisotope fractionation during aqueous photosynthesis: A paleo$\mathrm{pCO}_{2}$ barometer, Geology, 19, 929-932, doi:10.1130/00917613(1991)019<0929:CCOCIF > 2.3.CO;2, 1991.

Humbel, F. X.: Notice explicative, Carte pédologique de Ngaoundéré 1d à 1/50.000, ORSTOM, 164 pp., 1967.

Hustedt, F.: Die Kieselalgen, in: L. Rabenhorst's Kryptogamen, Flora von Deutschland, Osterreich und der Schweiz, Akademische Verlasgesellschaft Leipzig, 1 (1927-30), 920 pp., 2 (193159), 845 pp., 3 (1961-66), 816 pp., 1927-1966.

Hustedt, F.: Die Süsswasser-Flora Mitteleuropas, Bacillariophyta (Diatomeae), Verlag Von Gustav Fischer, Jena, 466 pp., 1930.

Jimenez-Lopez, C. and Romanek, C. S.: Precipitation kinetics and carbon isotope partitioning of inorganic siderite at $25^{\circ} \mathrm{C}$ and 1 atm, Geochim. Cosmochimi. Acta, 68, 557-571, 2004.

Kling, G. W.: Comparative limnology of lakes in Cameroon, West Africa, pHD Thesis, Duke University, 482 pp., 1987.

Kom, M. F.: Variations saisonnières des algues et des macrophytes dans les lacs et les marécages de la région de l'Adamaoua,: Relations avec les paramètres physicochimiques de l'eau, Unpublished Msc. Thesis. 74 pp., 2010.

Kossoni, A. and Giresse, P.: Interaction of Holocene infilling processes between a tropical shallow lake system (Lake Ossa) and nearby river system (Sanaga river) (South Cameroon), J. Afr. Earth Sci., 56, 1-14, 2009.

Krammer, K. and Lange-Bertalot, H.: Bacillariophyceae 1 Teil: Naviculaceae, 876 pp., 1986; 2 Teil: Bacillariaceae, Epithemiaceae, Surirellaceae, 596 pp., 1988; 3 Teil: Centrales, Fragilariaceae, Eunotiaceae, 576 pp., 1991a, 4 Teil: Achnantaceae, Kritische Ergänzungen zu Navicula (Lineolatae) und Gomphonema, 1991b, Sübwasserflora von Mitteleuropa 2/1-4, edited by: Ettl, H., Gerloff, J., Heynig, H., and Mollenhauer, D.,, Gustav Fischer, Stuttgart, 1986-1991.

Kutzbach, J. E. and Guetter, P. J.: The influence of Changing Orbital Parameters and Surface Boundary Conditions on Climate Simulations for the Past 18000 years, J Atmos. Sci., 43, 1726-1759, 1986.

Kutzbach, J. E. and Street-Perrott, F. A.: Milankovitch forcing of fluctuations in the level of tropical lakes from 18 to $0 \mathrm{kyr} \mathrm{BP}$, Nature, 317, 130-134, 1985.

Laws, E. A., Popp, B. N., Bidigare, R. R., Kennicutt, M. C., and Macko, S. A.: Dependence of phytoplankton carbon isotopic 
composition on growth rate and [CO2]aq: theoretical considerations and experimental results, Geochim. Cosmochim. Acta, 59, 1131-1138, 1995.

Leroux, M.: La dynamique des précipitations en Afrique Occidentale, Pub. Expl. Météo. ASECNA, Dakar, 23, 282 pp., 1970.

Leroux, M.: The Meteorology and Climate of Tropical Africa, Praxis, Chichester, UK, 548 pp., 2001.

Letouzey, R.: Etude phytogéographique du Cameroun, Encyclopédie Biologique, Paul Le Chevallier, Paris, 49, 508 pp., 1968.

Letouzey, R.: Notice sur la carte phytogéographique du Cameroun au 1:500 000, IRA, Yaoundé et Inst. Cart. Intern. Végétation, Toulouse, 5 vol., 1985.

Lezine, A. M.: Timing of Vegetation changes at the end of the Holocene Humid Period in Desert areas at the northern edge of the Atlantic and Indian monsoon systems, C. R. Geosci., 341, 750-759, doi:1016/j.crte.2009.01.001, 2009.

Maley, J.: Fragmentation de la forêt dense humide africaine et extension des biotopes montagnards au Quaternaire récent: Nouvelles données polliniques et chronologiques. Implications paléoclimatiques et biogéographiques, Palaeoeco A., 18, 307334, 1987.

Maley, J. and Brenac, P.: Vegetation dynamics, paleoenvironments and climatic changes in the forest of western Cameroon during the last 28000 years BP, Rev. Palaeobot. Palyno., 99, 157-187, 1998.

Meybeck, M.: Carbon, nitrogen, and phosphorous transport by world rivers, Am. J. Sci., 282, 401-450, 1982.

New, M., Lister, D., Hulme, M., and Makin, I.: A high-resolution data set of surface climate over global land areas, Clim. Res., 21, 1-25, 2000.

Ngomanda, A., Jolly, D., Bentaleb, I., Chepstow-Lusty A, M'voubou Makaya, Maley, J., Fontune, M., Oslisly, R., Rabenkogo, N.: Lowland forest response to hydrological changes during the last 1500 years in Gabon, Western equatorial Africa, Quaternary Res., 60, 411-425, 2007.

Ngomanda, A., Chepstow-Lusty, A., Makaya, M., Favier, C., Schevin, P., Maley, J., Fontugne, M., Oslisly, R., and Jolly, D.: Western equatorial African forest-savanna mosaics: a legacy of late Holocene climatic change?, Clim. Past, 5, 647-659, doi:10.5194/cp-5-647-2009, 2009a

Ngomanda, A., Neumann, K., Schweizer A., and Maley, J.: Seasonality change and third millennium BP rainforest crisis in southern Cameroon (Central Africa), Quaternary Res., 77, 307-318, 2009b.

Ngos III, S., Giresse, P., and Maley, J.: Palaeoenvironments of Lake Assom near Tibati (south Adamawa, Cameroon), What happened in Tibati around 1700 years BP?, J. Afr. Earth Sci., 37, 35-45, 2003.

Ngos, S., Sirocko, F., Lehné, R., Giresse, P., and Servant, M.: The evolution of the Holocene palaeoenvironment of the Adamawa region of Cameroon: evidence from sediments from two crater lakes near Ngaoundéré, in: Dynamics of Forest Ecosystems in Central Africa during the Holocene, Past-Present-Future, edited by: Runge, J., Balkema, 103-120, 2008.

Ngos III, S. and Giresse, P.: The Holocene sedimentary environments and the pyroclastic accumulations of two crater lakes (Mbalang, Tisong) of the volcanic plateau of Adamawa (Cameroon), Holocene, in press, 2011.

Nguetsop, V. F.: Evolution des environnements de l'Ouest Camer- oun depuis 6000 ans d'après l'étude des diatomées actuelles et fossiles dans le lac Ossa. Implications paléoclimatiques, Unpublished Thesis, Muséum National d'Histoire Naturelle, Paris, 278 pp., 1997.

Nguetsop, V. F., Servant, M., and Servant-Vildary, S.: Paléolimnologie et paléoclimatologie de l'Ouest-Cameroun au cours des 5000 dernières années, à partir de l'étude des diatomées du lac Ossa. C. R. Geosci. 327, 39-45, 1998.

Nguetsop, V. F., Servant-Vildary, S., and Servant, M.: Late Holocene climatic changes in West Africa, a high resolution diatom record from equatorial Cameroon, Quaternary Sci. Rev., 23, 591-609, 2004.

Nguetsop, V. F., Servant-Vildary, S., Servant, M., and Roux, M.: Long and short-time scale climatic variability in the past 5500 years in Africa according to modern and fossil diatoms from Lake Ossa (Western-Cameroon)m Glob. Planet. Change, 72, 356-367, 2010.

Nicholson, E. S.: A revised picture of the structure of the "monsoon" and land ITCZ over West Africa, Clim Dynam., 32, 11551171, doi:10.1007/s00382-008-0514-3, 2009.

Pourchet, M., Pinglot, J. F., and Maley, J.: Résultats des mesures radiochimiques de quelques lacs camerounais. Rapport CNRS Grenoble et ORSTOM Montpellier, 12 pp., 1987.

Reynaud-Farrera, I., Maley, J., and Wirrmann, D.: Végétation et climat dans les forêts du sud_Ouest du Cameroun depuis 4770 ans BP: analyse pollinique des sédiments du lac Ossa, CR. Acad. Sci. II A, Paris, 322, 749-755, 1996.

Roberts N., Reed, J. M., Leng, M. J., Kuzucuoğlu, C., Fontugne, M., Bertaux, J., Woldring, H., Bottena, S., Black, S., Hunt, E., and Karabıyıkoğlu, M.: The tempo of Holocene climatic change in the eastern Mediterranean region: new high-resolution craterlake sediment data from central Turkey, Holocene, 11, 721-736, 2001

Russell, J., Talbot, M. R., and Haskell, B. J.: Mid Holocene climate change in Lake Bosumtwi, Ghana, Quaternary Res., 60, 133$141,2003$.

Salzmann, U. and Hoelzmann, P.: The Dahomey gap: an abrupt climatically induced rain forest fragmentation in West Africa during the late Holocene, Holocene, 15, 190-199, 2005.

Salzmann, U., Hoelzmann, P., and Morczinek, I.: Late Quaternary climate and Vegetation of the Sudanian zone of Northeast Nigeria, Quaternary Res, 58, 73-83, 2002.

Schoeman, F. R.: Systematical and ecological study of the diatom flora of Lesotho with special reference to water quality, V and R Printers, Pretoria, 355 pp., 1973.

Servant, M. and Servant-Vildary, S.: L'environnement quaternaire du bassin du Tchad, in: The Sahara and the Nile, edited by: Williams, M. A. J. and Faure, H., Balkema, Rotterdam, 133-162, 1980.

Servant-Vildary, S.: Etude des diatomées et paléolimnologie du bassin Tchadien au Cénozoique supérieur, Travaux et Documents ORSTOM, (2 vol.), 84, 346 pp., 1978.

Simonsen, R.: Atlas and Catalogue of the diatom types of Friedrich Hustedt, edited by: Cramer, J., 1, 525 pp., 2, 597 pp., 3, 619 pp., 1987.

Stager, J. C. and Anfang-Sutter, R.: Preliminary evidence of environmental changes at Lake Bambili (Cameroon, West Africa) since 24,000 BP, J. Paleolimnol., 22, 319-330, 1999.

Stager, C. J., Cumming, B., and Meeker, L.: A high-resolution 
11,400 yr Diatom Record from Lake Victoria, East Africa, Quaternary Res., 47, 81-89, 1997.

Stuiver, M., and Reimer, P. J: Extended $14 \mathrm{C}$ database and revised CALIB radiocarbon calibration program, Radiocarbon, 35, 215 230, 1993.

Suchel, J. B.: Les climats du Cameroun, Unpublished Thesis, Université Saint-Etienne, 1188 pp., 1988.

Talbot, M. R. and Delibrias, G.: A new late Pleistocene-Holocene water-level curve for Lake Bosumtwi, Ghana, Earth Planet. Sci. Lett., 47, 336-344, 1980.

Talbot, M. R. and Johannenssen, T.: A high resolution paleoclimatic records for the last 27,000 years in tropical West Africa from the carbon and nitrogen isotopic composition of lacustrine organic matter, Earth Planet. Sci. Lett. 100, 23-37, 1992.

Tchouto, M. G. P., Yemefack, M., De Boer, W. F., De Wilde, J. J. F. E., Van de Maesen, L. J. G., and Cleef, A. M.: Biodiversity hotspots and conservation priorities in the Campo-Ma' an rain forests, Cameroon, Biodivers Conserv, 15, 1219-1252, 2006.

Vernet, R.: Climats anciens du Nord de l'Afrique, L'Harmattan, Paris, 180 pp., 1995.

Vincens, A., Buchet, G., Elenga, H., Fournier, M., Martin, L., de Namur, C., Schwartz, D., Servant, M., and Wirrmann, D.: Changement majeur de la végétation du lac Sinnda (vallée du Niari, Sud-Congo) consécutif à l'assèchement climatique holocène supérieur: apport de la palynologie, CR. Acad. Sci. II A, Paris, 318, 1521-1526, 1994.
Vincens, A., Buchet, G., Servant, M., and ECOFIT Mbalang collaborators: Vegetation response to the "African Humid Period" termination in Central Cameroon $\left(7^{\circ} \mathrm{N}\right)$ - new pollen insight from Lake Mbalang, Clim. Past, 6, 281-294, doi:10.5194/cp-6-2812010, 2010.

Vincens, A., Schwartz, D., Elenga, H., Reynaud-Farrera, I., Alexandre, A., Bertaux, J., Mariotti, A., Martin, L., Meunier, J.-D., Nguetsop, F., Servant, M., Servant-Vildary, S., and Wirrmann, D.: Forest response to climate changes in Atlantic Equatorial Africa during the last 4000 years BP and inheritance on the modern landscapes., J. Biogeor., 26, 879-885, 1999.

Watrin, J., Lezine, A. M., Hely, C., and Contributors: Plant migration and pollen communities at the time of the "green Sahara", CR. Geosci., 41, 656-670, 2009.

Weldeab, S., Schneider, R. R., Kölling, M., and Wefer, G. Holocene African droughs relate to eastern equatorial cooling, Geology, 33, 981-984, 2005.

Weldeab, S., Lea, D. W., Schneider, R. R., and Andersen, N.: Centennial scale climate instabilities in a wet early Holocene West African monsoon, Geophys. Res. Lett., 34, L24702 doi:10.1029/2007GL031898, 2007. 